\title{
A SUBORDINAÇÃO COMO ELEMENTO DO CONTRATO DE TRABALHO
}

\author{
SUBORDINATION AS AN ELEMENT OF THE EMPLOYMENT CONTRACT
}

Estêvão Mallet*

\begin{abstract}
Resumo:
$\mathrm{O}$ artigo examina a subordinação como elemento do contrato de trabalho, considerando o seu conceito, bem como os indícios de sua existência e a natureza do juízo formado a respeito.

Palavras-chave: Contrato de trabalho. Subordinação. Indícios de subordinação.
\end{abstract}

\begin{abstract}
:
The paper examines subordination as an element of the employment contract, considering the concept, as well as indications of its existence and the nature of the judgment formed in its respect.
\end{abstract}

Keywords: Employment contract. Subordination. Indications of subordination.

1. Introdução

Nem toda a prestação de serviço desenvolve-se no âmbito de um contrato de trabalho. Para que haja contrato de trabalho, no sentido jurídico da expressão, ou seja, no sentido do art. 442, da CLT, impõe-se seja o serviço prestado com a presença de certos elementos, sem os quais o trabalhador não se qualifica como empregado nem o tomador de serviços como empregador. Tais elementos, que bem podem ser ditos essentialia negotii do contrato de trabalho - ou elementos categoriais essenciais específicos do negócio jurídico correspondente ao contrato de trabalho ${ }^{1}$-, envolvem: a) atividade realizada por pessoa física ou natural; b) pessoalidade, ao menos em relação ao trabalhador; c) habitualidade; d) onerosidade e, finalmente, e) subordinação. Não são, como alguns imaginam, ${ }^{2}$ elementos do conceito de empregado, mas do próprio conceito de contrato de trabalho, ${ }^{3}$ até porque, conceituada a relação jurídica, ficam ipso facto conceituados os sujeitos que a integram.

\footnotetext{
* Professor de Direito do Trabalho e Vice-Presidente da Comissão de Pós-Graduação da Faculdade de Direito da Universidade de São Paulo, Conselheiro Seccional da Ordem dos Advogados do Brasil, Secção de São Paulo, Presidente do Conselho Curador da Escola Superior da Advocacia (ESA), da Ordem dos Advogados do Brasil, Secção de São Paulo, e advogado.

1 Sobre o conceito de elemento categorial essencial específico de cada negócio jurídico, cf. ANDRADE, Manuel A. Domingues de. Teoria geral da relação jurídica. Coimbra: Coimbra Editora, 2003. v. II, n. 63, p. 33, e, no Brasil, AZEVEDO, Antônio Junqueira de. Negócio jurídico - existência, validade e eficácia. São Paulo: Saraiva, 1986. p. 44.

2 NASCIMENTO, Amauri Mascaro. Iniciação ao direito do trabalho. São Paulo: LTr, 2004. p. 193 e ss.

3 MARTINEZ, Pedro Romano. Código do trabalho anotado. Coimbra: Almedina, 2008. p. 104.
} 
É corrente, especialmente na jurisprudência, mencionarem-se apenas quatro dos cinco elementos indicados, com omissão de atividade prestada por pessoa física ou natural ${ }^{4}$. A supressão do citado elemento funda-se na premissa de estar ele compreendido na referência à pessoalidade. A suposição é, no entanto, incorreta. A pessoalidade diz com o caráter infungível da prestação. ${ }^{5}$ Não implica necessariamente adimplemento por pessoa física. É perfeitamente concebível prestação de fazer infungível a cargo de pessoa jurídica, como no contrato em que não pode ser a atividade transferida a terceiro, por expressa disposição dos contratantes ou, conforme o exemplo de Antunes Varela, quando o contrato é celebrado tendo em conta o "prestígio da firma fornecedora". ${ }^{6}$ Logo, a mera infungibilidade subjetiva da prestação, ou seja, sua pessoalidade, não implica atividade desenvolvida por pessoa física. Daí a necessidade de mencionar-se, como elemento específico do contrato de trabalho, ao lado dos quatro usualmente lembrados, a realização da atividade por pessoa física.

Os cinco elementos apontados extraem-se da leitura conjugada dos arts. $2^{\circ}$, caput, e $3^{\circ}$, da CLT. O primeiro elemento encontra-se logo na parte inicial da definição de empregado, no art. $3^{\circ}$, da CLT: "Considera-se empregado toda pessoa física...". A pessoalidade acha-se mencionada na parte final do art. $2^{\circ}$ : “...prestação pessoal de serviço", sem constar do art. $3^{\circ} .^{7}$ A habitualidade corresponde à exigência, do art. $3^{\circ}$, de que os serviços sejam "de natureza não eventual". A onerosidade aparece nos dois dispositivos, ora pela menção ao empregador como sendo quem "assalaria" (art. $2^{\circ}$, caput), ora pela alusão ao empregado como aquele que trabalha "mediante salário" (art. $3^{\circ}$ ). Também a subordinação é mencionada em duplicidade, no art. $2^{\circ}$ com a referência ao empregador como o que "dirige" a prestação de serviços, e no art. $3^{\circ}$, com a identificação do empregado como sendo quem trabalha sob a "dependência" do tomador de serviço, em formulação muito próxima da que se encontra no Código Civil italiano de $1942 .{ }^{8}$

4 Por exemplo: TRT - $1^{\text {a }}$ Reg., $8^{\text {a }}$ T., RO n. 14698/96, Rel. Juiz João Mário de Medeiros in DJ de 10.02.98, p. 103; TRT - $15^{\mathrm{a}}$ Reg., $1^{\mathrm{a}}$ T., Ac. n. 18115/99, Rel. Juiz Lorival F. dos Santos in DJSP de 29.06.99, p. 75; TRT - $15^{\mathrm{a}}$ Reg., $3^{\mathrm{a}}$ T., Ac. $\mathrm{n}^{\circ}$ 40747/2000, Rel. Juiz Luís Carlos R. M. S. da Silva in DJSP de 06.11.2000, p. 2; TRT - 2 ${ }^{\mathrm{a}}$ Reg., $9^{\mathrm{a}}$ T., Proc. n. 01958000920095020021 , Rel. Juíza Jane Granzoto Torres da Silva, Ac. n. 20101059439 in DOE de 26.10.2010. Cf., ainda: “O reconhecimento do vínculo de emprego demanda, necessariamente, que a relação jurídica existente apresente, concomitantemente, os requisitos da alteridade, onerosidade, subordinação, pessoalidade e não eventualidade, previstos nos arts. $2^{\circ}$ e $3^{\circ}$ da CLT." (TRT - $2^{\mathrm{a}}$ Reg., 14 T. T., Proc RO n. 00192003620075020464 , Rel. Juiz Adalberto Martins, Ac. n. 20101239828).

RODRIGUES, Sílvio. Direito civil. São Paulo: Saraiva, ????, v. 2, n. 14, p. 36.

Das obrigações em geral, Coimbra, Almedina, 2007, vol. II, n. 281, p. 26.

Foi o que notou o seguinte precedente: “...o elemento da pessoalidade não consta literalmente do art. $3^{\circ}$ da CLT, trata-se de uma construção doutrinária e jurisprudencial, que, embora intimamente relacionada com a necessidade de prestação do serviço pela pessoa física, constitui requisito autônomo da relação empregatícia, erigido a tal status pelos doutrinadores e pelas decisões das Cortes trabalhistas do país. Portanto, incólume o art. $3^{\circ}$ da CLT" (TST - SDI II, ROAR n. 36600-86.2007.5.06.0000, Rel. Min. Emmanoel Pereira, julg. em 05.04.2011 in DEJT de 08.04.2011).

8 O Código Civil italiano define o empregado, no art. 2.094, sob a rubrica de prestatore di lavoro subordinato, como o trabalhador que, mediante retribuição, se obriga a colaborar na empresa, prestando serviço de caráter 
A ausência dos elementos indicados faz com que não se qualifique como contrato de trabalho a relação jurídica estabelecida. Se, por exemplo, o trabalhador pode fazer-se substituir por outrem, não há pessoalidade, descaracterizando-se a relação como de emprego. ${ }^{9}$ De igual modo, se o trabalho é prestado de modo gratuito, não oneroso, não há vínculo de emprego. ${ }^{10}$ Nas palavras de Manuel Alonso Olea, "el trabajo benévolo no es contrato de trabajo". ${ }^{11} \mathrm{O}$ mesmo se pode dizer dos demais elementos próprios do contrato de trabalho, habitualidade, subordinação e trabalho prestado por pessoa física.

De todos os cinco elementos, o mais importante é, sem sombra de dúvida, a subordinação, que a doutrina menciona como "uno dei concetti fondamentali del diritto del lavoro". ${ }^{12}$ Em torno dele é que se constrói, no fundo, o próprio Direito do Trabalho. É ele, outrossim, que delimita as principais fronteiras de aplicação da legislação trabalhista.

O conceito de subordinação, contudo, a despeito de sua importância, é também o mais complexo dos elementos do contrato de trabalho a identificar. Consoante a pertinente observação de Renato Corrado, a subordinação está longe de ser algo "evidente, come...può apparire a chi consideri le cose alla superficie". ${ }^{13}$ Muito pelo contrário, tratase, como escreve Mario Grandi, de conceito verdadeiramente enigmático, que "non si lascia facilmente afferrare, nel suo significato tipizzante, entre formule più o meno sintetiche". ${ }^{14}$ Daí a conveniência e a necessidade de examiná-lo mais detidamente.

"intellettuale o manuale alle dipendenze e sotto la direzione dell 'imprenditore".

9 Em termos muito expressivos, na jurisprudência: "Para que se reconheça a relação de emprego é necessário a pessoalidade, a não-eventualidade, o pagamento de salário e a subordinação jurídica ( $\operatorname{art} .3^{\circ}$ da CLT). A declaração do reclamante em Juízo de que caso não pudesse comparecer poderia arranjar um substituto e que chegou a ser substituído pelo seu irmão, comprova a ausência de pessoalidade, não havendo como reconhecer a relação de emprego." (TRT - $15^{\text {a }}$ Reg., $1^{\text {a }}$ T. Ac. n. 18115/99, Rel. Juiz Lorival F. dos Santos in DJSP de 29.06.99, p. 75). Na doutrina, de modo exemplificativo, RIVERO, Jean; SAVATIER, Jean. Droit du travail. Paris: PUF, 1989. p. 76.

10 "Vínculo de emprego. Onerosidade. Ausência de prova... Se o ponto nevrálgico é a onerosidade, enquanto requisito imprescindível ao reconhecimento do vínculo, e tal circunstância não foi trazida a tona após a fase probatória, não há como se concluir pela existência de relação de emprego entre as partes." (TRT - $10^{\mathrm{a}}$

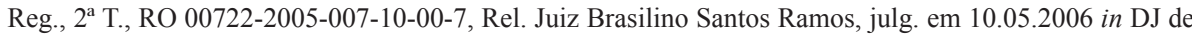
26.05.2006).

11 Derecho del trabajo, Madrid, Universidad de Madrid, 1974. p. 13, bem como, novamente, Jean Rivero e Jean Savatier, que escrevem: "Il n'y a...pas de contrat de travail si les services sont fournis gratuitement" (Droit du travail cit., p. 76). Não tem razão Pontes de Miranda, portanto, ao afirmar ser possível alguém empregar-se, "com todos os pressupostos do contrato de trabalho, mas gratuitamente", o que permitiria a aplicação das regras atinentes à relação individual de emprego, "exceto no que se referem à remuneração" (Tratado de direito privado, Rio de Janeiro, Borsoi, 1964, tomo XLVII, § 5.096, p. 447). Muito pelo contrário, a ausência de onerosidade, como a falta de qualquer um dos outros elementos essenciais para a caracterização do contrato de trabalho, impede a configuração do vínculo de emprego. Sobre o ponto, com exame do problema a partir da hipótese de prestação não onerosa de serviço, na forma da Lei n. 9.608, cf. Estêvão Mallet, Trabalho gratuito in Direito, Trabalho e Processo em transformação, São Paulo, LTr, 2005, p. 42 e ss.

12 GRANDI, Mario. Rapporto di lavoro. Enciclopedia del diritto, Varese, Giuffrè, 1987, XXXVIII, p. 322.

13 CORRADO, Renato. Trattato di diritto del lavoro. Torino: UTET, 1966. v. 2, n. 111, p. 245.

14 GRANDI, Mario. Rapporto di lavoro. cit., p. 322. 
2. Aspectos não essenciais da subordinação

A subordinação própria do contrato de trabalho não é, vale a pena realçar logo de início, a simples dependência econômica do trabalhador, decorrente de sua menor capacidade financeira, a impor-lhe a necessidade de trabalhar, para prover sua subsistência. Construção do gênero, que no passado contou com algum prestígio, ${ }^{15}$ foi logo deixada de lado. Consoante realçado com indiscutível acerto em antigo pronunciamento da Corte de Cassação francesa, "la condition juridique d'un travailleur à l'égard de la personne pour laquelle il travaille ne saurait être déterminée par la faiblesse ou la dépendance économique dudit travailleur". ${ }^{16}$ E hoje a doutrina reafirma a proposição. Jacques Le Goff anota, ao tratar do tema, que "la subordination économique n'implique pas salariat". ${ }^{17}$ $\mathrm{Na}$ doutrina portuguesa, Pedro Romano Martinez sublinha bem que a "dependência econômica não caracteriza o contrato de trabalho". ${ }^{18}$

Realmente, tanto pode prestar serviço de forma subordinada o trabalhador dotado de amplos meios econômicos, ${ }^{19}$ ou que conta pelo menos com outras fontes de renda, como o que se acha deles desprovido, ainda que se deva admitir, do ponto de vista prático, ser menos frequente a primeira situação do que a última. Em sentido inverso, também pode haver dependência econômica sem que haja contrato de trabalho, tal como se dá no caso do pequeno empreiteiro que presta serviços a um só tomador e depende dos valores por ele pagos para prover suas necessidades vitais. Enfim, como resumem Orlando Gomes e Élson Gottschalk, ao repudiar a definição do contrato de trabalho a partir da dependência econômica, o critério é falho, pois "não pode ser característico de um contrato elemento que pode existir ou não existir nesse contrato". ${ }^{20}$ Por isso, a dependência a que alude o art. $3^{\circ}$, da CLT, não é nem pode ser vista como dependência econômica, como já deixou expresso a jurisprudência. ${ }^{21}$

Do mesmo modo, a subordinação presente no contrato de trabalho não se confunde - ao menos não de modo necessário - com a menor capacidade negocial

15 CUCHE, Paul. Du rapport de dépendance, élement constitutif du contrat de travail. Revue critique, 1913, p. 412.

16 Chambre Civile, decisão de 06.07.1931, Préfet de la Haute-Garonne c. Bardou apud Les grands arrêts du droit du travail (PÉLISSIER, Jean (Org.). Antonine Lyon-Caen, Antoine Jeammadu, Emanuel Dockès), Paris, Dalloz, 2008, p. 3.

17 LE GOFF, Jacques. Droit du travail et société. Rennes: Presses Unviersitaires de Rennes, 2001. p. 124.

18 MARTINEZ, Pedro Romano. Código do Trabalho anotado. cit., p. 105.

19 RUSSOMANO, Mozart Victor. Comentários à CLT. Rio de Janeiro: Forense, 1985. p. 15.

20 GOMES, Orlando; GOTTSCHALK, Élson. Curso de direito do trabalho. Rio de Janeiro: Forense, 2006. n. 55, p. 136.

21 Assim, acertadamente: “...o conceito de 'dependência' referid(o) no art. $3^{\circ}$ da CLT, há muito já restou definid(o) pela jurisprudência de que não se trata de 'dependência econômica' mas sim 'jurídica', ou seja, subordinação.” (TRT - 4ª Reg., 4 a T., RO n. 0083700-12.2003.5.04.0201, Rel. Juíza Flávia Lorena Pacheco, julg. em 09.12.2004). 
do trabalhador. ${ }^{22}$ Ainda que normalmente se encontre o empregado de fato em posição de inferioridade negocial, pelo constrangimento que tem de encontrar trabalho, a fim de prover suas necessidades vitais, sem que tenha meios de adiar a satisfação delas, ${ }^{23}$ conceitualmente pode prestar serviço subordinado o trabalhador com ampla capacidade de negociação. É o que ocorre com profissionais renomados e com grande prestígio como jogadores de futebol e outros desportistas, por exemplo -, os quais algumas vezes chegam a ponto de impor condições para a celebração do contrato. E o fazem no quadro da prestação subordinada serviços, consoante os termos da Lei n. 9.615, não em regime de trabalho autônomo, sem vinculação empregatícia.

Nem mesmo o mero fato de inserir-se o trabalhador na estrutura empresarial, exercendo serviço ligado à atividade-fim da empresa e observando, ainda, determinações do empresário, basta à caracterização da subordinação pertinente ao contrato de trabalho, ao contrário do que se afirma em alguns julgados, a partir da tentativa de construção da figura da subordinação estrutural, integrativa ou reticular. ${ }^{24} \mathrm{~A}$ ideia, no fundo, nem é nova. Envolve recuperação e tentativa de atualização de velha doutrina, subjacente à regra do art. 2.094, do Código Civil italiano - mais remotamente vinculada à doutrina germânica do contrato de trabalho como resultado da Eingliederung do trabalhador na empresa-instituição ${ }^{25}$-, da subordinação como inserção na estrutura produtiva, por meio da colaboração do empregado com a empresa. No entanto, consoante a advertência de António Lemos Monteiro Fernandes, "o contrato de prestação de serviço pode harmonizarse com a inserção funcional dos resultados da actividade (art. 1154 do Cód. Civ.) no metabolismo da organização empresarial". ${ }^{26}$ Mais uma vez a jurisprudência nacional sublinha o ponto, em aresto digno de referência: “A eventual sujeição do trabalhador ao poder de organização do proprietário do estabelecimento não se confunde com a subordinação jurídica que decorre do art. $3^{\circ}$ da CLT...". ${ }^{27}$

22 Ainda GRANDI, Mario. Rapporto di lavoro... cit. p. 323.

23 Para exame mais demorado das circunstâncias econômicas que desequilibram a negociação entre empregados e empregadores, OFFE, Claus. A economia política do mercado de trabalho. In: Capitalismo desorganizado. São Paulo: Brasiliense, 1995. p. 24 e ss.

24 TRT - $11^{\text {a }}$ Reg., $1^{\text {a }}$ T., RO n. 0180600-58-2009-5-11-000-5, Rel. Juíza Maria das Graças Alecrim Marinho, DOJTAM de 04.10.2010 in Revista Magister de Direito Trabalhista e Previdenciário, Porto Alegre, set/out 2010, vol. 38, p. 117; TRT - 24ª Reg., $2^{\text {a }}$ T., RO n. 00345-2008-005-24-00-0, Rel. Juiz Francisco das C. Lima Filho, julg. em 01.04.2009 in DO/MS n 523 de 17.04.2009 e TRT - 3 ${ }^{\text {a }}$ Reg., 4 $4^{\mathrm{a}}$ T., RO n. 00531-2008018-03-00-0, Rel. Juiz Convocado José Eduardo de Resende Chaves Júnior in DJMG de 18.10.2008. Em doutrina, a propósito, Luciano Martinez, Curso de direito do trabalho, São Paulo, Saraiva, 2010, p. 117, e Gustavo Filipe Barbosa Garcia, Curso de direito do trabalho, São Paulo, Método, 2009, n. 8.5.4, p. 145.

25 ICHINO, Pietro. Il contrato di lavoro. Milano: Giuffrè, 2000. n. 82, p. 271-272.

26 FERNANDES, António Lemos Monteiro. Direito do trabalho. Almedina: Coimbra, 1999. p. 144. Para algumas anotações sumárias sobre a teoria da inserção ou da integração, cf., na doutrina nacional, mas com indicação de doutrina alemã, HIRATA, Alessandro. Relações contratuais fáticas. São Paulo: s. e. p. (tese), 2011, p. 22 e ss., especialmente p. 25-26.

27 TRT $-2^{\text {a }}$ Reg., $12^{\text {a }}$ T., Proc. $n^{\circ} 01307200604302009$, Rel. Juiz Adalberto Martins, Ac. n. 20070739484,julg. em 30.08.2007 in Revista Synthesis, v. 46/08, p. 189. Em termos semelhantes: "Relação de 


\section{Vínculo obrigacional e subordinação}

Tampouco se materializa a subordinação trabalhista na mera sujeição do prestador de serviço a algumas diretrizes ou, em termos gerais, a determinadas obrigações. Em outras palavras, não se confunde a subordinação com a simples necessidade de seguir, na execução do trabalho, certas regras. Entendê-la de tal modo, com tamanha amplitude ou largueza, levaria a resultado claramente absurdo, na medida em que todo o contrato, de uma forma ou de outra, cria, pela sua mera natureza obrigatória, vínculo entre as partes contratantes. Qualquer relação jurídica, como lembra Manuel Domingues de Andrade, tem, como elemento passivo, "uma obrigação (dever jurídico ou sujeição)". ${ }^{28}$ Por isso mesmo anota Renato Corrado que "ogni rapporto implica un vincolo e quindi la dipendenza di un soggetto da altro soggetto". ${ }^{29}$ Em consequência - e o texto é de Evaristo de Moraes Filho - "em todos os negócios jurídicos, em que haja credor e devedor, fica este sempre subordinado de certa forma àquele". ${ }^{30}$

No âmbito dos contratos de prestação de serviços em geral - portanto até mesmo no âmbito da prestação autônoma de serviço -, há parâmetros mínimos de comportamento emergentes do liame obrigacional. Pode-se estabelecer o dia em que o trabalho será realizado, bem como o horário ou o local em que isso irá ocorrer. Ainda assim, é perfeitamente concebível não se estar diante de contrato de trabalho, porquanto "não há como confundir diretivas, orientações gerais, conselhos, com subordinação jurídica estrita". ${ }^{31}$ Como escreve Bernardo da Gama Lobo Xavier, "a autonomia do

emprego. Não caracterização. Pedreiro autônomo. O traço definidor da situação de empregado não está na subordinação simplesmente, mas no grau ou intensidade desta subordinação. Necessário, portanto, aferir-se as características do serviço prestado, para se concluir sobre a existência, ou não, da relação de emprego. $\mathrm{O}$ fato de que o reclamante, pedreiro, comparecesse habitualmente para prestar trabalho e que havia fiscalização do serviço, no sentido de se ditar(em) os parâmetros da construção civil, não faz presumir existência de subordinação jurídica, mas, tão-somente, organização do serviço a ser executado." (TRT - $3^{\mathrm{a}}$ Reg., 5 ${ }^{\text {a }}$ T., RO n. 00109-2004-088-03-00-1, Rel. Juiz Emerson José Alves Lage, julg. em 06.07.2004 in DJMG de 10.07.2004, p. 14).

28 ANDRADE, Manuel Domingues de. Teoria geral da relação jurídica. Coimbra: Almedina, 1997. v. 1, n. 33, p. 187.

29 CORRADO, Renato. Trattato di diritto del lavoro. cit., v. 2, n. 111, p. 246.

30 MORAES FILHO, Evaristo de. Vendedora autônoma.In: Pareceres de Direito do Trabalho. São Paulo: LTr, 1976. p. 138. Analogamente, CESARO, Jean-François. La subordination em Les notions fondamentales du droit du travail. Paris: LGDJ, 2009. p. 141; com a afirmação de que "c'est le propre du contrat que de générer des obligations et donc d'entamer la liberté". Em jurisprudência: "Vínculo empregatício. Inexistência. Requisitos. Demonstrado que o reclamante podia dispor de seu tempo com liberdade e autonomia na realização de suas tarefas, traço característico do prestador de serviços autônomos, impossível o reconhecimento do vínculo empregatício, ante a ausência dos requisitos do art. $3^{\circ}$ consolidado. $\mathrm{O}$ fato de haver preposto da empresa a supervisionar os trabalhos desenvolvidos não desqualifica a condição autônoma da prestação de serviços, adredemente pactuada pelas partes, eis que, conforme assevera Maurício Godinho Delgado, "dificilmente existe contrato de prestação de serviços em que o tomador não estabeleça um mínimo de diretrizes e avaliações básicas à prestação efetuada...'...”. (TRT - $10^{\mathrm{a}}$ Reg., $1^{\mathrm{a}}$ T., Proc. n. 00034.2003.006.10.009, Rel. Juíza Maria Regina Machado Guimarães in DJ de 10.10.2003).

31 MORAES FILHO, Evaristo de. Vendedora autônoma. cit., p. 138. 
trabalho não é incompatível com a execução de certas directivas da pessoa servida e de algum controle desta sobre o modo como o serviço é prestado". ${ }^{32} \mathrm{Na}$ expressão da Corte de Cassação belga, não basta à caracterização da subordinação inerente ao contrato de trabalho "le simple exercice d'un contrôle ou la simple communication de directives dans le cadre d'une convention de travail à caractère indépendant". ${ }^{33}$

Tome-se, como exemplo concreto do que acaba de ser dito, o contrato autônomo de representação comercial, disciplinado pela Lei n. 4.886. Dele decorrem, para o representante, várias obrigações. Algumas bastante precisas, como, entre outras, a de prestar "informações detalhadas sobre o andamento dos negócios a seu cargo", ${ }^{34}$ a de não conceder abatimentos ou dilações "salvo autorização expressa", ${ }^{35} \mathrm{ou}$, ainda, a de observar a "zona ou zonas em que será exercida a representação". ${ }^{36} \mathrm{Nem}$ assim há, no caso, subordinação trabalhista, ${ }^{37}$ conquanto se possa aludir à subordinação lato sensu, como já se viu em jurisprudência. ${ }^{38}$

Em termos mais amplos, nos restantes contratos civis de prestação de serviço, em que igualmente não está presente - como soa óbvio - a subordinação típica do contrato de trabalho, fica o prestador constrangido também a observar determinados parâmetros e a respeitar certas regras, quer no tocante à atividade a ser desenvolvida, quer, em alguns casos, no que diz respeito à forma de seu desenvolvimento. No contrato de mandato, embora ausente a subordinação trabalhista, não deixa o mandatário de estar obrigado a dar conta de suas atividades ao mandante, nos termos do art. 668, do Código

32 XAVIER, Bernardo da Gama Lobo. Curso de direito do trabalho. Lisboa: Verbo, 1993. p. 302. Cf., ainda, Ubaldo Prosperetti, que se refere à presunção da subordinação, "sia pure in modo molto attenuato, in alcune forme di lavoro autonomo" (PROSPERETTI, Ubaldo. Il lavoro subordinato. Milano: Francesco Valladri, 1964. n. 24, p. 38). Na doutrina nacional, sempre no mesmo sentido, MORAES FILHO, Evaristo de. Vendedora autônoma. cit., p. 140.

33 Cour de cassation, troisième chambre, processo n. S.10.0073.N, Office National de Sécurité Sociale v. S. P., decisão de 06.12.2010.

34 Art. 28, da Lei n. 4.886.

35 Art. 29, da Lei n. 4.886.

36 Art. 27, alínea "d", da Lei n. 4.886.

37 "Representante comercial. Autonomia. Controle ou fiscalização pelo representado. Inexistência de subordinação. A autonomia do representante comercial não se descaracteriza pelo fato de o representado exercer algum tipo de controle ou fiscalização sobre a atividade daquele, pois esta tem previsão legal (art. 28 da Lei n. 4.886/65), de forma que o exercício desse direito pelo representado não enseja a subordinação típica da relação de emprego" (TRT - 24ª Reg., RO n. 721/97, Rel. Juíza Geralda Pedroso, Ac. n. 2.308, julg. em 24.09.1997 in DJ de 12.11.1997, DJ-MS nº 004652, p. 53).

38 “....a Lei 4.886/65...estabelece, para o representante comercial, além do serviço não eventual (artigo $1^{\circ}$ ), certos elementos que, a rigor, serviam para definir a subordinação...”. (TRT - $3^{\mathrm{a}}$ Reg., $2^{\mathrm{a}} \mathrm{T}$., RO n. 00834200104803008, Rel. Juíza Alice Monteiro de Barros, julg. em 05.02.2002 in DJMG de 09.02.2002, p. 09); "Representante comercial autônomo e contrato de trabalho... O fato de o reclamante prestar contas não quer dizer isoladamente que havia subordinação, pois a prestação de contas também é inerente ao representante comercial autônomo diligente, que deve mostrar ao representado o que vendeu, inclusive para poder receber as suas comissões. Vínculo de emprego não reconhecido." (TRT - $2^{\mathrm{a}}$ Reg., $3^{\mathrm{a}}$ T., Proc. RO n. 02970005144, 1997, Ac. n. 02980000102, Rel. Juiz Sérgio Pinto Martins in DOE de 13.01.1998). 
Civil. ${ }^{39} \mathrm{O}$ diretor de sociedade anônima, por sua vez, sujeita-se às diretrizes estabelecidas pelos órgãos competentes da sociedade e mesmo à fiscalização pela assembleia-geral. Nem por isso cabe falar na existência da subordinação própria do contrato de trabalho, conclusão sedimentada em jurisprudência a partir da Súmula 269, do Tribunal Superior do Trabalho. ${ }^{40}$ Consoante decidido pela Corte de Cassação francesa, "les directives émanant du conseil d'administration ne suffisent pas à créer un lien de subordination". ${ }^{41}$ Daí a justa ponderação de Juan Ramírez Gronda, de que "la subordinación...no es nota exclusiva del contrato de trabajo, pues, en mayor o menor grado, aparece contenida también en la locación de servicios y en el mandato". ${ }^{42}$

Aliás, até fora do campo estritamente contratual não são raras as situações em que a pessoa natural se encontra, no cumprimento da atividade que lhe cabe desempenhar, vinculada a certas regras, sem que caiba falar em subordinação, no sentido trabalhista do termo. Os magistrados, por exemplo, gozam da mais ampla liberdade na condução dos processos e na decisão das causas que lhe são submetidas a julgamento. ${ }^{43}$ Como enunciado pela Constituição de Portugal, estão sujeitos apenas à lei, ${ }^{44} \mathrm{o}$ que significa, em verdade, sujeição unicamente ao direito legitimamente posto. ${ }^{45} \mathrm{~A}$ independência - cuja amplitude não poderia ser maior - é, no fundo, atributo para a qualificação de qualquer órgão como judiciário. ${ }^{46}$ Sem embargo, devem os magistrados respeitar prazos e horários. Chega a lei

39 "Não há vínculo empregatício na relação de representação, onde o representante, investido de poderes para gerir os negócios do mandante, em nome deste pratica todos os atos necessários à administração do empreendimento.” (TRT - 23 $3^{\text {a }}$ Reg., $1^{\text {a }}$ T., RO n. 00329.2008.041.23.00-6, Rel. Juiz Edson Bueno, julg. em 05.05.2009 in DJ de 11.05.2009).

40 "O empregado eleito para ocupar cargo de diretor tem o respectivo contrato de trabalho suspenso, não se computando o tempo de serviço desse período, salvo se permanecer a subordinação jurídica inerente à relação de emprego".

${ }^{41}$ Chambre Sociale, processo n. 84-42315, decisão de 28.01.1988. Sobre a mesma questão, em caso em que envolvido diretor de sociedade anônima, assentou o Supremo Tribunal de Justiça de Portugal: "A circunstância de o autor estar sujeito às deliberações da assembleia geral e às resoluções do órgão a que presidia não consubstancia o dever de obediência às ordens dadas pela entidade patronal (art. $20^{\circ}, \mathrm{n} .1$, al. c) da LCT), pois que estas resoluções e deliberações sempre obrigam todas e cada uma das pessoas que constituem o elemento pessoal do substracto de qualquer ente colectivo, porque representam a vontade deste através dos seus órgãos competentes para tal, pelo que o autor devia cumprir as deliberações da Assembleia Geral e proceder em conformidade com as decisões da Direcção, decisões em cujo processo formativo participava na qualidade de presidente deste órgão." (STJ - Processo 03S2053, Rel. Vítor Mesquita, julg. em 30.09.2004).

42 GRONDA, Juan Ramírez. El contrato de trabajo em Tratado de derecho del trabajo. Buenos Aires: La Ley, 1971. tomo I, p. 576. Também assim, na doutrina nacional, PINTO, José Augusto Rodrigues. Tratado de Direito Material do Trabalho. São Paulo: LTr, 2007. n. 39, p. 125.

43 O art. 765, da CLT, expressamente assinala: "Os Juízos e Tribunais do Trabalho terão ampla liberdade na direção do processo e velarão pelo andamento rápido das causas, podendo determinar qualquer diligência necessária ao esclarecimento delas".

44 Art. $203^{\circ}$, verbis: "Os tribunais são independentes e apenas estão sujeitos à lei".

45 Sobre a melhor interpretação para a regra do art. 203, da Constituição de Portugal, com indicação das diferentes alternativas oferecidas pela doutrina, cf. MIRANDA, Jorge; MEDEIROS, Rui. Constituição portuguesa anotada. Coimbra: Coimbra Editora, 2007. tomo III, p. 38 e ss.

46 A propósito, registra pronunciamento do Tribunal Constitucional de Portugal: "tribunais hão-de ser 
brasileira a aludir à obrigação de que compareçam "pontualmente à hora de iniciar-se o expediente ou sessão". ${ }^{47}$ Ademais, ficam sujeitos ao poder disciplinar dos órgãos próprios, sem que haja quebra, só por isso, de sua independência. ${ }^{48}$ A ninguém ocorre dizer serem os magistrados trabalhadores subordinados, como o são os empregados.

Por fim, em outros domínios evidencia-se a existência de poder disciplinar, com prerrogativa imposição de sanções tipicamente aplicáveis a empregados, como advertência, suspensão e desvinculação da atividade, sem que esteja presente relação de emprego. É o que se vê no âmbito do trabalho portuário. Mesmo não sendo empregado o trabalhador avulso, fica ele sujeito ao poder disciplinar exercido pelo Órgão Gestor de Mão de Obra, nos termos da Lei n. 8.630, podendo ser sancionado com advertência, suspensão e cancelamento de registro. ${ }^{49}$

\section{A subordinação própria do contrato de trabalho}

Do que se disse anteriormente tira-se a necessidade de diferenciar, com mais rigor, a subordinação inerente ao contrato de trabalho da mera existência de regras impostas para a prestação de serviço ou, pode-se bem dizer, da subordinação em termos gerais, decorrente de todo contrato ou do estatuto legal, mas insuficiente para a configuração do vínculo de emprego. Teve oportunidade de realçar a jurisprudência, no particular: "Vínculo de emprego. Parceria rural. Inexistência. Para a caracterização da relação de emprego, no caso em tela, em que há uma lei regulando o exercício da parceria rural, os requisitos elencados no art. $3^{\circ}$ da CLT devem ser cabalmente demonstrados, pois ordens a serem cumpridas em decorrência do contrato assumido não implicam o reconhecimento de subordinação jurídica, mas, tão-somente, subordinação contratual. Assim, em não havendo o preenchimento dos requisitos supracitados, não há falar em vínculo de emprego". ${ }^{50}$ À mesma conclusão já chegara a jurisprudência portuguesa, como se vê de aresto oriundo do Supremo Tribunal de Justiça, em que convém apenas ressalvar

visualizados como sendo só aqueles órgãos de soberania que, exercendo funções jurisdicionais, sejam suportados por juízes que desfrutem totalmente de independência funcional e estatutária" (Processo: n. 286/90, Ac. n. 171/92, Rel. Cons. Bravo Serra).

47 Lei Complementar n. 35, art. 36, inciso VI.

48 Mais uma vez pode-se citar a jurisprudência do Tribunal Constitucional de Portugal: "sendo um órgão jurisdicional, claro está que a referida secção do Supremo Tribunal de Justiça beneficia da independência que o artigo 203 da Constituição confere a todos os tribunais sem excepção. Independência que, numa dimensão interna, implica que nenhum tribunal está subordinado a instruções hierárquicas de outro, sem prejuízo do instituto dos recursos e da existência de uma ordem judicial. Esta independência não é afectada, evidentemente, pela inevitável sujeição dos juízes a um poder disciplinar e pela consagração de um mecanismo de nomeação de juízes. Se assim fosse, então nenhum tribunal seria, afinal, independente."(Processo n. 614/98, Ac. 290/99, Rel. Cons ${ }^{a}$ Maria Fernanda Palma).

49 Art. 19, inciso I.

50 TRT - 12 ${ }^{\mathrm{a}}$ Reg., RO-V n. 10.465/2000, Rel. Juiz Telmo Joaquim Nunes, Ac. n. 02338, julg. em 06.02.2001 in $\mathrm{DJ} / \mathrm{SC}$ de 12.03.2001, p. 112. 
a imperfeita referência a "empregador", quando mais acertado seria o termo "tomador de serviço": "O poder de fiscalização do empregador relativamente ao trabalhador não constitui característica específica do contrato de trabalho subordinado, sendo comum a outras formas contratuais como o contrato de empreitada". ${ }^{51}$

$\mathrm{Na}$ verdade, a subordinação própria do contrato de trabalho é mais do que a necessidade de o trabalhador seguir certas regras na prestação do serviço, ainda quando impostas pelo beneficiário do trabalho, titular do empreendimento. Compreende a prerrogativa, de que se investe o tomador de serviço, em decorrência da relação de emprego, de modular, a cada passo ou quando queira, segundo as conveniências do negócio - observados, é óbvio, os limites legais e contratuais próprios -, a atividade exercida pelo trabalhador, determinando o trabalho a ser feito, a forma, o local e o momento de sua realização, ${ }^{52}$ bem como fiscalizando, durante a prestação de serviço, o cumprimento das ordens dadas e, quando pertinente, sancionando o descumprimento delas. Como decidiu a Corte de Cassação francesa, em julgado que se tornou paradigmático no tema, a subordinação típica do contrato de trabalho "est caractérisé par l'exécution d'un travail sous l'autorité d'un employeur qui a le pouvoir de donner des ordres et des directives, d'en contrôler l'exécution et de sanctionner les manquements de son subordonné". ${ }^{53}$ Nas apropriadas e mais sintéticas palavras de De Ferrari, a subordinação é "a possibilidade que tem uma das partes de imprimir, quando o creia necessário, uma certa direção na atividade alheia" ${ }^{4}$ ou, como prefere Arion Sayão Romita, é a "determinação, pelo empregador, das modalidades de prestação de trabalho". ${ }^{55}$ É a subordinação, portanto, a faculdade que tem o empregador de "indicare, attraverso ordini, le singole operazioni da solvegere e di controllare i risultati raggiunti" ${ }^{56}$

$51 \quad$ STJ - Processo n. 01S4283, Rel. Mário Torres, decisão de 20.02.2002. Em termos semelhantes, do mesmo Supremo Tribunal de Justiça, pode-se citar outro precedente, com ementa assim redigida: "Num contrato de prestação de serviços nada impede que possam existir ordens ou instruções da parte do beneficiário do serviço, dirigidas ao objecto do resultado e não à forma de o cumprir, sem que isso signifique subordinação jurídica do prestador do serviço ao beneficiário deste.” (STJ - Processo n. S2020, Rel. Mário Torres, decisão de 15.11.2000).

52 "the right to direct what the alleged employee shall do and the details of how he shall do it", consoante a expressão da United States Court of Appeals for the Ninth Circuit em Stahl v. United States, caso n. 10 35006, decisão de 29.11.2010.

53 Arrêt "Société Générale”, de 13 novembro de 1996, publicado no Boletim da Corte de Cassação n. 386 p. 275. Também pode ser encontrado em Les grands arrêts du droit du travail cit., p. 4. A mesma proposição reaparece em julgado mais recente, Processo n. 10-15.573, decisão de 28.04.2011, da Chambre Sociale, reproduzido no Boletim da Corte de Cassação n. 747, de 15.09.2011, sob n. 998.

54 Apud Paulo Emílio Ribeiro de Vilhena, Relação de emprego - Estrutura legal e supostos, São Paulo, LTr, 1999, p. 470.

55 A subordinação no contrato de trabalho, Rio de Janeiro, Forense, 1979, p. 82.

56 CORRADO, Renato. Trattato di diritto del lavoro. cit., v. 2, n. 121, p. 269. 
É, pois, a forma como se desenvolve a atividade, com a ampla sujeição do trabalhador, durante o exercício do trabalho, às diretrizes traçadas pelo tomador de serviço, que define a subordinação peculiar ao contrato de trabalho. ${ }^{57}$

5. Identificação da subordinação própria do contrato de trabalho

Apreender o conceito de subordinação - como se procurou fazer no item anterior - por si só não basta para resolver o problema da qualificação de determinada relação jurídica concreta como contrato de trabalho ou como contrato de outra natureza. Nem sempre é fácil apurar, diante de determinados fatos, se estão ou não presentes circunstâncias bastantes para falar-se em subordinação trabalhista. Como adverte a doutrina francesa, a noção de subordinação, "devant l'infinie variété et la complexité des situations contractuelles...se revele souvent d'une application délicate". ${ }^{58}$ Há mesmo quem diga, com algum excesso, não ser concebível "un concetto contenutisticamente unitario di lavoro subordinato". 59

Pode haver, para retomar aspecto já indicado anteriormente, obrigação de cumprimento de horário e de comparecimento em certos dias da semana ou do mês, mas, de outra parte, maior liberdade no exercício da atividade. É o caso de afirmar-se a existência de contrato de trabalho ou, ao contrário, as obrigações estabelecidas são compatíveis com a figura da prestação autônoma de serviços? Não há como enunciar abstratamente a resposta, em termos válidos para todas as diferentes situações. De acordo com a United States Supreme Court, diante de casos duvidosos sobre a existência ou não de relação de emprego, "there is no shorthand formula or magic phrase that can be applied to find the answer".${ }^{60}$ Como bem adverte a doutrina, por conta da necessidade de organizar temporalmente a atividade de vários prestadores autônomos de serviço, que convergem para a realização de uma única obra, no mesmo local, "pode um trabalhador, por exemplo, um médico da empresa, ter de se apresentar em horário predeterminado (todas as segundas das $15 \mathrm{~h} 00$ às $17 \mathrm{~h} 00$ ), e isso não ser suficiente para que o contrato seja qualificado como contrato de trabalho". ${ }^{61}$ Somente o exame de cada situação, de cada realidade, "via l'observation des donnés de fait" ${ }^{62}$ sopesadas as peculiaridades do trabalho e a condição das pessoas que nele se envolvem, ${ }^{63}$ permite chegar a alguma conclusão.

57 Na jurisprudência: “...o que norteia a caracterização do contrato de trabalho é a subordinação jurídica, cuja existência ou não deve ser investigada no "modus faciendi" da prestação dos serviços." (TRT - 2a Reg., $1^{\text {a }}$ T., RO n. 02486-2003-008-02-0, Rel. Juiz Plínio Bolivar de Almeida, Ac. n. 20060053326, julg. em 09.02.2006 in DOE SP, PJ de 07.03.2006).

58 CAMERLYNCK, G. H. Traité de Droit du Travail: contrat de travail. Paris: Dalloz, 1968. n. 31, p. 51.

59 SANSEVERINO, Luisa Riva. Diritto del lavoro. Padova: CEDAM, 1971. n. 33, p. 49.

$60 \quad$ NLRB v. United Insurance Co., (390 U.S. 254; a passagem citada encontra-se a p. 258).

${ }_{61}$ GOMES, Júlio Manuel Vieira. Direito do Trabalho. Coimbra: Coimbra Editora, 2007. v. 1, p. 132.

62 TEYSSIE, Bernard. Droit du Travail - Relations individuelles de travail, Paris, Litec, 1992, n. 408, p. 221.

63 LYON-CAEN, Gerard; PELISSIER, Jean; SUPIOT, Alain. Droit du travail. Paris: Dalloz, 1994. p. 164. 
Por isso é que o "comportamento...individualizado (é)...el momento real de diversificación entre los...esquemas" do contrato autônomo de prestação de serviço e do contrato de trabalho. ${ }^{64}$ Impossível, pois, fugir completamente do estudo casuísta da hipótese concreta, para determinar se se está ou não diante de contrato de trabalho. ${ }^{65}$ Como realçado em pronunciamento do Judicial Committee do Privy Council do Reino Unido, a determinação da natureza jurídica do vínculo por meio do qual uma pessoa presta serviços a outra reclama "an investigation and evaluation of the factual circumstances in which the work is performed". ${ }^{6}$

A despeito do assinalado, há certos aspectos ou circunstâncias que funcionam como indicativos da existência ou não da subordinação própria do contrato de trabalho. São elementos auxiliares na busca da qualificação da relação jurídica, cada vez mais invocados no Direito do Trabalho, especialmente nos sistemas jurídicos dos países europeus ${ }^{67}$. Alguns autores denominam-nos "présomptions", ${ }^{68}$ há os que falam em "índices" $"$, outros aludem a "traços distintivos", ${ }^{70}$ enquanto predomina a expressão "indícios de subordinação jurídica", ${ }^{71}$ seguramente a mais adequada e a mais encontrada na jurisprudência comparada. ${ }^{72}$

Antes de mencionar esses indícios, cumpre ter em conta - como a todo momento se proclama - que isoladamente um ou outro deles não basta para qualificar ou desqualificar a relação jurídica como contrato de trabalho. Nenhum é "decisivo por si só", ${ }^{73}$ conclusão referendada pela United States Supreme Court ${ }^{74}$ e por outros tribunais

64 RIVAS, Daniel. La subordinacion: criterio distintivo del contrato de trabajo. Montevideo: Fundacion de Cultura Universitaria, 1995. p. 110.

65 JACOBS, Antoine T. J. M. Labour Law in the Netherlands. The Hague: Kluwer, 2004. n. 41, p. 47.

66 Lee Ting Sang Appellant v. Chung Chi Keung and Shun Shing Construction \& Engineering Co. Ltd., Appeal n. 44 de 1989; [1990] 2 AC 374.

${ }^{67}$ Cf. Alain Supiot e outros (org.), Transformações do Trabalho e futuro do Direito do Trabalho na Europa, Coimbra, Coimbra Editora, 2003, n. 60, p. 33.

68 CAMERLYNCK, G. H. Traité de droit du travail... cit., n. 31, p. 52.

69 XAVIER, Bernardo da Gama Lobo. Curso de direito do trabalho. cit., p. 302.

70 CORDEIRO, António Menezes. Manual de direito do trabalho. Coimbra: Almedina, 1999. p. 533.

71 RAMALHO, Maria do Rosário Palma. Direito do trabalho: situações laborais individuais. Coimbra: Almedina, 2006. p. 33. Também adota a expressão "indícios de subordinação" (FERNANDES, António Lemos Monteiro. Direito do trabalho. cit., p. 143).

72 Na jurisprudência portuguesa, com menção a "indícios de subordinação", por exemplo, as seguintes decisões do Supremo Tribunal de Justiça: processo 07S1800, Rel. Sousa Grandão, acórdão de 10.10.2007; processo 002430, Rel. Sousa Macedo, acórdão de 26.09 .90 e, ainda, processo 99S097, Rel. José Mesquita, acórdão de 18.11.99.

73 GOMES, Júlio Manuel Vieira. Direito do trabalho... cit., v. I, p. 130. A conclusão é tranquila em doutrina. Cf., entre outros autores, Joana Nunes Vicente, A fuga à relação de trabalho (típica): em torno da simulação e da fraude à lei, Coimbra, Coimbra Editora, 2008. p. 120, e Patrick Humblet e Marc Rigaux, Aperçu du droit du travail belge, Bruxelles, Bruylant, 2004, n. 50, p. 43.

74 Por exemplo, Nationwide Mut. Ins. Co. v. Darden (503 U.S. 318, com a citação pertinente a p. 324). 
norte-americanos. ${ }^{75}$ Como disse Frederico Marques, "o indício, só por si, nada prova". ${ }^{76}$ Mas a reunião de vários deles é um importante ponto para, em casos duvidosos e na falta de elementos mais precisos, alcançar resultado adequado na investigação, a partir de "juízo global". Nas palavras de Mummery, referendadas pela decisão da Chancery Division da High Court of Justice britânica, no conhecido caso Hall v. Lorimer, "In order to decide whether a person carries on business on his own account it is necessary to consider many different aspects of that person's work activity. This is not a mechanical exercise of running through items on a check list to see whether they are present in, or absent from, a given situation. The object of the exercise is to paint a picture from the accumulation of detail. The overall effect can only be appreciated by standing back from the detailed picture which has been painted, by viewing it from a distance and by making an informed, considered, qualitative appreciation of the whole". ${ }^{77}$

6. Indícios de subordinação e de ausência de subordinação

Constitui indício de subordinação jurídica trabalhista, própria do contrato de trabalho, em primeiro lugar, a sujeição a horário de trabalho, ${ }^{78}$ sendo indício do contrário a ausência de controle do gênero, de modo a ter o trabalhador, como registrado em decisão da Suprema Corte dos Estados Unidos, "discretion over when and how long to work". ${ }^{79}$ De acordo com Maria do Rosário Palma Ramalho, "de um modo geral, o trabalhador subordinado encontra-se adstrito a um determinado horário de trabalho, que delimita temporalmente a sua disponibilidade perante o empregador; pelo contrário, no trabalho autônomo, a gestão do tempo de trabalho compete habitualmente ao prestador" ${ }^{80}$ No direito belga, a Lei-Programa (I), de 27 de dezembro de 2006, menciona, como indício de inexistência de relação de emprego, "la liberté d'organisation du temps de travail". ${ }^{81}$ Nessa linha, já decidiu o Tribunal Superior do Trabalho: "Consignado pelo Tribunal Regional ter a diarista liberdade na fixação de seu horário e dia de atendimento, afasta-se a indicada ofensa ao art. 333, inciso II, do Código de Processo Civil. Não configuradas a subordinação e a continuidade para reconhecimento do vínculo, ou seja, não se desincumbiu a reclamante de comprovar os elementos fáticos (art. 333, inciso I, CPC) constitutivos do direito que perseguia (reconhecimento do vínculo de emprego)". ${ }^{82}$

\footnotetext{
75 Cf. a já citada decisão tomada pela United States Court of Appeals for the Ninth Circuit em Stahl v. United States, caso n. 10-35006.

76 Instituições de direito processual civil. Rio de Janeiro: Forense, 1959. v. III, n. 822, p. 483.

77 [1993] EWCA Civ 25.

78 PROSPERETTI, Ubaldo. Il lavoro subordinato. cit., n. 33, p. 50.

79 Community for Creative Non-violence v. Reid (490 U.S. 730; a citação pertinente encontra-se a p. 751).

80 Direito do trabalho... cit., p. 35.

81 Art. 333, $\S 1^{\circ}$.

${ }^{82}$ TST - 5 ${ }^{\mathrm{a}}$ T., RR n. 533.739/99, Rel. Min. João Batista Brito Pereira, julg. em 20.03.2002 in DJU de 12.04.2002.
} 
Também a forma de remuneração do trabalho serve de indício relevante para determinar se há ou não subordinação e, portanto, se se trata ou não de contrato de trabalho. ${ }^{83}$ Nas palavras de Pedro Romano Martinez, "(S)e o pagamento é feito à tarefa, em princípio, estar-se-á perante um contrato de prestação de serviço, mas se for determinado por tempo de trabalho será de pressupor que se trata de um contrato de trabalho". ${ }^{84}$ Assim, a regularidade dos valores e dos pagamentos - ainda mais quando desvinculados da quantidade de serviço ${ }^{85}$ - aponta para o contrato de trabalho, ao passo que "montantes incertos e sem regularidade" indicam realidade jurídica diversa. ${ }^{86}$

O local em que se dá a prestação de serviço não deixa de ter sua importância, ${ }^{87}$ ainda que, como já dito, não se confunda a subordinação com a inserção do trabalhador na estrutura da empresa. Na linha do disposto no art. 12 , n. 1, letra "a", do Código do Trabalho de Portugal, com a redação dada pela Lei n. 7/2009, de 12 de fevereiro, o fato de ser a atividade realizada em local pertencente a quem se beneficia do serviço ou em local por tal pessoa estabelecido é indicativo da existência de relação de emprego. Diversamente, quando o prestador de serviço tem liberdade para desenvolver sua atividade onde melhor lhe convém, há indício de inexistência de relação de emprego. Na jurisprudência portuguesa, colhe-se precedente em que se assentou, sobre o ponto: “A subordinação jurídica...deduz-se - na ausência de comportamentos declarativos expressos definidores das condições do exercício da actividade contratada, situação frequente quando se trata de convénios informais - de factos indiciários, todos a apreciar em concreto e na sua interdependência, sendo os mais significativos:...o local de trabalho situar-se nas instalações do empregador ou onde ele determinar...". ${ }^{88}$

Tal qual o local de trabalho, a propriedade dos equipamentos de trabalho - "the source of the instrumentalities and tools", na expressão da United States Supreme

83 Novamente Community for Creative Non-violence v. Reid (490 U.S. 730; a citação pertinente encontra-se a p. 751).

${ }_{84}$ Direito do trabalho. Coimbra: Almedina, 2007. p. 315. No mesmo sentido, RAMALHO, Maria do Rosário Palma. Direito do trabalho... cit., p. 35, bem como LE GOFF, Jacques. Droit du travail et société. cit., p. 129.

85 O ponto foi invocado em julgado de que se extrai o seguinte argumento, utilizado, ao lado de outros, para a caracterização da relação como vínculo de emprego: “...o documento de fl. 44, juntado aos autos pela própria reclamada, demonstra que os dois elementos mais importantes para a caracterização do vínculo empregatício, quais sejam, subordinação jurídica e salário, estiveram presentes ao longo da prestação de serviço. Aliás, merece destaque a declaração da testemunha Alessandro José Lopes de que "[...] o recte podia se recusar a fazer as viagens; que, se o recte se recusasse a fazer todas as viagens durante o mês, mesmo assim recebia o pagamento de R\$5.100,00 mensais; [...].” (ata de fl. 124). Portanto, mesmo que o reclamante não cumprisse a meta estipulada, o salário era pago integralmente." (TRT - $3^{\mathrm{a}}$ Reg., $5^{\mathrm{a}}$ T., Proc. RO n. 01741-2007-075-03-00-9, Rel. Juiz Lucilde D’Ajuda Lyra de Almeida in DJMG de 27.09.2008).

86 CORDEIRO, António Menezes. Manual de direito do trabalho. cit., p. 533.

87 Ainda Community for Creative Non-violence v. Reid, em que se menciona "the location of the work" como um dos elementos para a determinação da existência ou não de relação de emprego (490 U.S. 730; a citação encontra-se a p. 751).

88 STJ - Proc. 295/07.9TTPRT.S1, Rel. Vasques Dinis, decisão de 19.05.2010. 
Court, em Community for Creative Non-violence v. Reid ${ }^{89}$-, é também indício a ser considerado. Afinal, pertencerem os instrumentos de trabalho ou as ferramentas utilizadas na execução do serviço ao trabalhador indica relação não empregatícia, de caráter autônomo. Em Stahl v. United States a United States Court of Appeals for the Ninth Circuit invocou também, para justificar o reconhecimento da existência de contrato de trabalho, o fato de o tomador de serviço fornecer "to its workers, including its members, all of the tools and equipment necessary to its business operation. Those include "[t] rucks, tractors, diggers, balers, tillage, [and][e]very tool a mixed farming operation needs" ${ }^{\prime 90}$. No direito português, o Código do Trabalho presume a existência de relação de emprego sempre que "os equipamentos e instrumentos de trabalho utilizados pertençam ao beneficiário da actividade". ${ }^{91}$ Já o Decreto-Lei n. 328/93, que disciplina o regime geral de segurança social dos trabalhadores independentes, presume a ausência de subordinação quando "o trabalhador tenha, no exercício da sua atividade, a faculdade de escolher os processos e meios a utilizar, sendo estes, total ou parcialmente da sua propriedade". ${ }^{92}$

Ademais, é preciso considerar, como aspecto de grande relevância, que "a emissão de ordens directas e o controlo da prestação do trabalhador apontam para a sua subordinação e, nessa medida, para a qualificação laboral do contrato; já a simples sujeição a instruções genéricas e a um controlo de resultados pode apontar para o trabalho autónomo". ${ }^{93}$ Mais uma vez pode-se recorrer à jurisprudência nacional, a fim de ilustrar o indício mencionado: "Presença dos requisitos configuradores do vínculo de emprego... Subordinação às ordens da reclamada, que dirigia e coordenava os trabalhos, tanto no aspecto técnico, como disciplinar". ${ }^{94}$

Com os indícios apontados, vai-se além da singela presunção da natureza empregatícia do vínculo, a partir da mera prova ou admissão da prestação de serviço, presunção frequentemente mencionada na jurisprudência nacional ${ }^{95}$ e estabelecida,

490 U.S. 730; a passagem transcrita encontra-se a p. 751.

Caso n. 10-35006, decisão de 29.11.2010.

Art. $12^{\circ}$, n. 1., letra "b".

Art. $5^{\circ}$, n. 1, letra "a".

RAMALHO, Maria do Rosário Palma. Direito do trabalho: situações laborais individuais cit., p. 36-37.

TRT $-4^{\text {a }}$ Reg., $3^{\text {a }}$ T., RO n. 94.023108-5, Rel. Juiz Pedro Luiz Serafini, julg. em 25.07.1996 in DJRS de 26.08.1996.

95 Entre tantos precedentes, cf., de modo ilustrativo, TRT - 13a Reg., Ac. n. 8.958/92, Rel. Juiz Brandão Libânio in DJPB de 18.03.92, p. 12; TRT - 21 $1^{\text {a }}$ Reg., Ac. n. 101/92, Rel. Juiz Miranda Monte in DJRN de 02.09.92, p. 10; TRT - 3a Reg., $1 \stackrel{a}{a}$ T., Proc. RO n. 1.555/92, Rel. Juiz A. Paoliello in DJMG de 22.01.93, p. 4; TRT - 9a Reg., 2aㅗ T., Ac. n. 9.628/93, Rel. Juiz L. Stellfeld in DJPR de 03.09.93, p. 226; TRT - $10^{\mathrm{a}}$ Reg., $3^{\text {a }}$ T., RO n. 01020-2008-001-10-00-5, Rel. Juíza Heloisa Pinto Marques, julg. em 26.05.2009 in DJ de

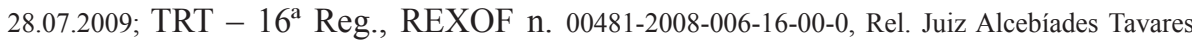
Dantas, julg. em 24.03.2010 in DJ de 28.04.2010. Em termos críticos à ideia de que bastaria ao trabalhador provar a prestação de serviço, para recair sobre o tomador de serviço o ônus de provar o caráter autônomo do trabalho, cf. Antônio Vallebona, L'onere della prova nel diritto del lavoro, Padova, CEDAM, 1988, n. 12, p. 102. 
de modo expresso, em alguns ordenamentos jurídicos. ${ }^{96} \mathrm{~A}$ inferência que se pretende estabelecer, com a presunção criada, é demasiado larga e pouco traz de seguro quanto ao resultado do julgamento. Afinal, muitas são as situações em que há prestação de serviço sem que esteja configurado o contrato de trabalho.

7. O valor relativo e variável dos indícios de subordinação e de ausência de subordinação

De qualquer sorte, o valor dos indícios mencionados no item anterior varia conforme a natureza da atividade, o ramo da empresa e a função desempenhada pelo prestador de serviço. O peso de cada um é relativo. Há que ter na devida consideração tal aspecto.

Se o local da prestação de serviço pode ser relevante em algumas situações, em outras tem menor ou nenhum significado. Na hipótese de trabalho prestado por motorista, o fato de o serviço desenvolver-se externamente não prejudica em nada a caracterização da relação de emprego, como se afigura evidente, pois é antes decorrência necessária da natureza da atividade. Outro tanto pode-se dizer a propósito do teletrabalho, que nada tem de ontologicamente incompatível com o vínculo de emprego, como se afigura óbvio. ${ }^{97}$ A Corte de Cassação francesa pôde enunciar que a previsão, no contrato de trabalho, de prestação de serviço no próprio estabelecimento da empresa " $n$ 'exclut pas que les parties aient pu convenir d'un mode d'organisation du travail de la salariée en tout ou partie en télétravail" ${ }^{98}$ Não por outro motivo teve o legislador o cuidado de explicitar - evidentemente sem levar em conta a figura do teletrabalho, não imaginada na altura e não assimilável perfeitamente ao trabalho em domicílio ${ }^{99}$ - a possibilidade de caracterização de contrato de trabalho mesmo para serviços prestados na própria residência do empregado, consoante a regra do art. $6^{\circ}$, da CLT.

96 É o que se vê, por exemplo, no direito mexicano, em que se encontra, no art. 21, da Ley Federal del Trabajo a seguinte previsão: "Se presumen la existencia del contrato y de la relación de trabajo entre el que presta un trabajo personal y el que lo recibe".

97 GONIÉ, Jean. Le télétravail en France: les principaux points de la recommandation du Forum des droits sur l'Internet. Droit Social, mars, 2005, n. 3, p. 275. A definição de teletrabalho, formulada no Accord national interprofessionnel sur le télétravail, de 19 de julho de 2005, mostra bem a compatibilidade da figura com o trabalho subordinado. Estabelece o art. $1^{\circ}$, do acordo, que se entende por teletrabalho "une forme d'organisation et/ou de réalisation du travail, utilisant les technologies de l'information dans le cadre d'un contrat de travail et dans laquelle un travail, qui aurait également pu être réalisé dans les locaux de l'employeur, est effectué hors de ces locaux de façon régulière".

98 Chambre Sociale, processo n. 06-43524, decisão de 29.11.2007.

99 O teletrabalho pode muito bem desenvolver-se em local outro que não a residência do empregado. E o trabalho em domicílio pode prescindir do recurso a tecnologias de informação e comunicação, necessárias no teletrabalho. Por isso, como adverte João Leal Amado, o teletrabalho "não deve ser confundido com a figura tradicional do "trabalho no domicílio" "(Contrato de trabalho. Coimbra: Coimbra Editora, 2010. p. $159)$. 
De modo análogo, a ausência de sujeição a controle de horário, que pode ter importância em alguns casos, mostra-se pouco significativa em se tratando de trabalhador vinculado a posição diretiva ou gerencial. Em tal hipótese, a liberdade de horário é decorrência da natureza especial do vínculo, conforme art. 62, II, da CLT, não indício de autonomia na prestação de serviço. Em outro contexto, a falta de controle do horário de entrada e de saída do trabalhador, se indica alguma liberdade na modulação da atividade, torna-se menos relevante em caso de compensação de horário. Passa a ser mais o reflexo de novas formas de realização do trabalho - em que ganha espaço alguma autodeterminação, do ponto de vista organizativo, do serviço pelo trabalhador ${ }^{100}$ - do que indício da autonomia incompatível com a subordinação peculiar à relação de emprego.

Comentário semelhante cabe para as atividades de natureza intelectual, nas quais a subordinação manifesta-se de forma diferenciada. A direção do trabalho, pelo empregador, exsurge com tons mais tênues, menos salientes, o que nada tem de excepcional, pois, segundo a doutrina francesa, "la subordination ne suppos(e)...pas le controle étroit et constant de toutes les facettes de l'activité du travailleur; elle p(eut) se conjuguer avec une certaine liberté de ce dernier". ${ }^{101}$ Como acertadamente assinalado em jurisprudência, "é preciso afeiçoar a subordinação jurídica, com atenuação da rigidez, em casos envolvendo atividades de natureza eminentemente intelectual, para chegar a uma adaptação mais consentânea com as particularidades de cada hipótese, isoladamente considerada na discussão quanto à existência de vinculação empregatícia...". ${ }^{102}$

Aliás, as transformações das formas de produção, inclusive com a descentralização empresarial, a terceirização de atividades e o crescimento do setor de serviços, fazem com que, na identificação da subordinação trabalhista, se tenha cada vez menos de levar em conta os parâmetros próprios do trabalho realizado em tempos pretéritos, em ambiente fabril ou industrial. ${ }^{103}$ Em linhas gerais, a subordinação no escritório não se exterioriza como a subordinação na fábrica. Mais ainda, não é descabido falar em verdadeira atenuação da subordinação, ${ }^{104}$ que dia a dia mais se aproxima de simples "supervisão", por parte do empregador, da atividade realizada. Na sociedade contemporânea, diversamente do que ocorria nos primeiros tempos da industrialização, contam mais as capacidades de criação e de iniciativa do que a disciplina. A criatividade passa a ser "le pricipal facteur de production", como lembra Pierre Rosanvallon. ${ }^{105}$

100 GRANDI, Mario. Rapporto di lavoro... cit., p. 329.

101 CESARO, Jean-François. La subordination... cit., p. 133.

102 TRT $-3^{\text {a }}$ Reg., $4^{\mathrm{a}}$ T., RO n. 0069800-38.2007.5.03.0107, Rel. Juiz Júlio Bernardo do Carmo, julg. em 12.08.2009 in DJMG de 24.08.2009.

103 ASSIS, Rui de. O poder de direcção do empregador: configuração geral e problemas actuais. Coimbra: Coimbra Editora, 2005. p. 43.

104 Id. Ibid., p. 43.

105 ROSANVALLON, Pierre. La société des égaux. Paris: Seuil, 2011. p. 300. 
Ao mundo da planificação, presente na fábrica fordista, sucede o mundo da adaptação permanente, no qual cresce, de maneira inexorável, a autonomia dos trabalhadores, "même dans le cas d'emploi apparemment répétitifs", enfatiza o mesmo autor. ${ }^{106}$ Os empregados de hoje "doivent être en mesure de prendre des initiatives, de répondre à l'imprévu en résolvant les problèmes qui surgissent, d'exercer leur responsabilité". ${ }^{107}$ Por isso Alain Supiot refere-se a uma progressiva diluição da subordinação, provocada pelas novas formas de organização do trabalho e pelos progressos técnicos. ${ }^{108}$ Nas palavras encontradas em acórdão do Tribunal do Trabalho da $3^{\text {a }}$ Região, "as novas e modernas formas de prestação de serviços avançam sobre o determinismo do art. $3^{\circ}$, da CLT...a subordinação...continua a ser o mesmo instituto, mas com traços modernos, com roupagem diferente". ${ }^{109}$

A forma de pagamento, indicativa de autonomia quando materializada em participação do prestador de serviço no resultado da atividade, em certos setores diz muito pouco, por ser usual a prática de ganho por resultado também para empregados. Aliás, não se deve perder de vista a possibilidade de concessão de lucros - forma de remuneração típica de relação societária - a empregados, inclusive sem posição de maior relevo na empresa. ${ }^{110}$ Inversamente, pagamento calculado por hora, mais característico de contrato de trabalho, algumas vezes constitui tão somente "a convenient way of arriving at the fair price for the job performed by an independent contractor". ${ }^{111}$ São bem conhecidos os casos de pagamento de advogados autônomos, técnicos de informática autônomos ou consultores sem vínculo de emprego por meio de honorários calculados por tempo de atividade.

Por fim, liberdade decisória relativamente a certos aspectos da execução do serviço, ainda que completa e absoluta, nem sempre implica ausência da subordinação inerente ao contrato de trabalho. Em alguns domínios, especialmente em questões técnicas, liberdade do gênero é compatível com a relação de emprego. ${ }^{112}$ Pense-se no comandante de aeronave. A ele cabe decidir, do ponto de vista da segurança do voo, sobre a decolagem ou não. Pode, portanto, cancelar a partida ou adiar a sua realização, se considerar não estarem presentes as condições exigidas. É expresso o direito positivo. ${ }^{113}$

\footnotetext{
106 Id. Ibid., p. 301.

107 Id. Ibid., p. 301.

108 SUPIOT, Alain. Critique du droit du travail. Paris: PUF, Quadriage, 2002. p. 260.

109 TRT - $3^{\text {a }}$ Reg., $4^{\text {a }}$ T., RO n. 00073-2005-103-03-00-5, Rel. Juiz Luiz Otavio Linhares Renault, julg. em 21.09.2005 in DJMG de 01.10.2005.

110 Cf., no Direito brasileiro, a Lei n. 10.101.

111 ANDERSON, Gordon et al. Employment Law Guide. Wellington: LexisNexis NK Ltd., 2005. p. 169.

112 Jacques Le Goff, Droit du travail et société cit., p. 125, Joana Nunes Vicente, A fuga à relação de trabalho (típica) cit., p. 119, e, com menção a vários precedentes jurisprudenciais, Bernadette Lardy-Pélissier, Jean Pélissier, Agnès Roset, Lysiane Tholy, Le nouveau Code du Travail annoté, Paris, Groupe Revue Fiduciaire, 2011, p. 37.

113 Cf. art. 169, da Lei n. 7.565/86.
} 
Sob tal perspectiva, não se sujeita às ordens de seu empregador. Goza da mais ampla e completa liberdade, sem nenhuma ingerência do empregador. Nem há como o sancionar por ter decidido, dentro de suas atribuições, pelo cancelamento do voo. Ainda que da decisão resulte prejuízo econômico ou de outra ordem para o empregador, prevalece a autonomia decisória do piloto, desde que, naturalmente, não haja abuso. Mas permanece, ainda assim, a subordinação própria do contrato de trabalho, já que não lhe é dado cancelar o voo por motivo de sua conveniência pessoal ou por outra razão assemelhada. $\mathrm{O}$ mesmo vale, no aspecto técnico, para o médico. Como assinala a doutrina, "a autonomia técnica e deontológica dos médicos não é incompatível com um contexto de subordinação". ${ }^{114}$ Outro tanto cabe dizer do advogado empregado. É expressa, aliás, a Lei n. 8.906, que, ao regular a profissão, estatui: “A relação de emprego, na qualidade de advogado, não retira a isenção técnica nem reduz a independência profissional inerentes à advocacia". ${ }^{115}$

No fundo, a verdade é que a subordinação característica do contrato de trabalho varia de intensidade, indo de um grau maior para um grau menor, na medida em que, "dal lavoro prevalentemente materiale, si passa al lavoro prevalentemente intellettuale". ${ }^{116}$ Em outros termos, quanto maior o aspecto intelectual do trabalho, menor tende a ser a intensidade da subordinação e vice-versa. Não é desarrazoada, aliás, a contraposição que Pontes de Miranda esboça entre subordinação e confiança, para dizer que o crescimento desta última encobre parte daquela, ${ }^{117}$ ainda que não a faça desaparecer, dando-lhe, apenas, formas e características novas.

8. A qualificação do contrato feita pelas partes e o comportamento correspondente

Ao lado dos indícios já listados, há mais um que vale ainda mencionar, inclusive para que seja compreendido em sua devida medida.

É certo que, diante do princípio da primazia da realidade e mesmo da regra do art. $9^{\circ}$, da CLT, a mera qualificação de determinada relação jurídica como contrato de prestação de serviço, feita pelas partes nela envolvidas, não basta para afastar

114 Joana Nunes Vicente, A fuga à relação de trabalho (típica) cit., p. 119, nota 240. Cf., ainda, RIVERO, Jean; SAVATIER, Jean. Droit du travail. cit., p. 80.

115 Art. 18.

116 SANSEVERINO, Luisa Riva. Diritto del lavoro. cit., n. 34, p. 50, e ASSIS, Rui de. O poder de direcção do empregador. cit., p. 42/43. Na doutrina nacional, cf. BARROS, Alice Monteiro de. Curso de direito do trabalho. São Paulo: LTr, 2009. p. 301. Em jurisprudência: “...o trabalhador intelectual, mesmo sendo empregado, exerce suas atividades com uma liberdade maior, pois, em alguns casos, sua formação intelectual e teórica é superior à do próprio empregador, não reproduzindo a subordinação dos antigos paradigmas de sujeição estrita a ordens ou submissão a horários ou comparecimentos diários...A subordinação, portanto, como no caso em análise, não deixa de existir, principalmente se o trabalho é exercido por conta e risco do empregador. Recurso conhecido e não provido." (TRT - 16 $6^{\mathrm{a}}$ Reg., RO n. 00743-2007-006-16-00-5, Rel. Juiz Luiz Cosmo da Silva Júnior, julg. em 29.07.2008 in DJ de 04.09.2008).

117 MIRANDA, Francisco Cavalcanti Pontes de. Tratado de direito privado. cit., tomo XLVII, § 5.055, p. 91. 
eventual natureza empregatícia da relação, ainda que se confira a tal qualificação a mais ampla solenidade e formalidade. A natureza da relação determina-se pela realidade da prestação de serviço, não pela forma jurídica ou denominação dada ao vínculo. $\mathrm{Na}$ clássica e sintética formulação de Mario de la Cueva, sempre lembrada, "la realidad no se niega por una declaración". ${ }^{118}$ A assertiva dispensa mais longa demonstração, já que muito bem assentada em doutrina, ${ }^{119}$ na legislação comparada ${ }^{120}$ e em jurisprudência, ${ }^{121}$ mesmo estrangeira, a ponto de a Corte de Cassação francesa haver assinalado, certa feita: "l'existence d'une relation de travail ne dépend ni de la volonté exprimée par les parties ni de la dénomination qu'elles ont donnée à leur convention mais des conditions de fait dans lesquelles est exercée l'activité des travailleurs". ${ }^{122}$ Os tribunais norte-americanos não divergem. A Court of Appeal da Califórnia, por exemplo, decidiu que "the parties' label is not dispositive and will be ignored if their actual conduct establishes a different relationship". ${ }^{123}$ Aliás, dado o seu caráter geral, o enunciado vale até no direito comum ${ }^{124}$, de modo a permitir que se afirme que a real natureza de um contrato ou acordo "sobrepõese à falsa denominação que lhe tenha sido atribuída". ${ }^{125}$

Cumpre ter o cuidado de não atribuir valor absoluto à proposição, todavia. Uma coisa é dizer que não podem as partes desnaturar, pelo simples uso de certa forma contratual, a relação jurídica. Coisa muito diversa é privar de relevância a qualificação do

118 DE LA CUEVA, Mario. El nuevo derecho mexicano del trabajo. México: Porrúa, 2007. p. 195.

119 RODRIGUEZ, Américo Plá. Princípios de direito do trabalho. São Paulo: LTr, 2000. p. 367; João Leal Amado, que resume nos seguintes termos a assertiva: "os contratos são o que são, não o que as partes dizem que são” (AMADO, João Leal. Contrato de trabalho. cit., p. 72).

120 Conforme o Employment Relations Act da Nova Zelândia, de 2000, para decidir sobre a existência ou não de contrato de trabalho entre trabalhador e tomador de serviço, é preciso considerar "the real nature of the relationship between them" [Seção 6, (2)]. Na Lei-Programa (I) belga, de 27 de dezembro de 2006, é insuficiente para "qualifier adéquatement la relation de travail: l'intitulé de la convention" (art. $333, \S 3^{\circ}$ ).

121 "Para configuração da relação de emprego importa essencialmente o que ocorre no terreno dos fatos. É irrelevante que outra denominação seja emprestada à figura jurídica que envolve prestação pessoal de serviços, quando demonstrada, pela presença dos elementos que tipificam a existência da relação de emprego (Aplicação do Princípio da Primazia da Realidade).” (TRT - 1ª Reg., 7a T., RO n. 10535/92, Rel. Juiz Ricardo A. Oberlaender in DJRJ de 05.07.95, p. 230). Cf., ainda, TST - 7ª T., AI-RR n. 689 689/2004142-06-40.6, Rel. Min. Pedro Paulo Manus, julg. em 17.09.2008 in DJU de 19.09.2008; TST - $3^{\mathrm{a}}$ T., AIRR n. 1629 1629/2004-202-01-40.7, Rel. Min. Carlos Alberto Reis de Paula, julg. em 08.10.2008 in DJU de 14.11.2008.

122 Processo n. 98-40572, arrêt "Labbane", de 19 de dezembro, de 2000, publicado no Boletim da Corte de Cassação n. 437. Também pode ser encontrado em Les grands arrêts du droit du travail cit., p. 5.

123 Estrada v. FedEx Ground Package System, Inc. (2007)154 Cal.App.4th, 11, 64 Cal. Rptr. 3d 327. De igual modo, do mesmo tribunal: "a party's use of a label to describe a relationship with a worker does not create a material dispute over whether an employment relationship existed; such a label will be ignored where the evidence of their actual conduct establishes that a different relationship exists"(Futrell v. Payday California, Inc. (2010), Cal. App. 4th., p. 18/19).

124 No dizer de João Leal Amado, trata-se de verdadeiro “princípio geral do Direito.” (AMADO, João Leal. Contrato de trabalho. cit., p. 72).

125 TELLES, Inocêncio Galvão. Manual dos contratos em geral. Coimbra: Coimbra Editora, 2002. n. 131, p. 254. 
contrato feita pelas partes. Conforme a advertência de Júlio Manuel Viera Gomes, "afirmarse que não se deve ficar vinculado pelo nomen iuris que as partes deram ao contrato quando este nome não corresponde com a realidade da sua execução não é sinônimo de negar qualquer relevância à vontade das partes nesta operação de qualificação". ${ }^{126}$

Realmente, a denominação contratual utilizada pelas partes, como a própria forma contratual escolhida, se não é decisiva - e não é mesmo -, quando menos constitui indício suplementar para a mais exata qualificação do vínculo jurídico estabelecido entre elas. ${ }^{127}$ Serve, em situações menos claras, para orientar a resolução da dificuldade em torno da qualificação jurídica da relação, na medida em que pode indicar "la volontà negoziale" 128 das partes. Como assentado pela Court of Appeal inglesa, ao julgar o caso Young \& Woods Limited v. Cyril William West, "it is by now well settled that the label which the parties choose to use to describe their relationship cannot alter or decide their true relationship; but, in deciding what that relationship is, the expression by them of their true intention is relevant, but not conclusive". ${ }^{129}$

$\mathrm{Na}$ jurisprudência portuguesa é constante o recurso à qualificação feita pelas partes como aspecto a ser considerado na determinação da natureza jurídica do vínculo. O Supremo Tribunal de Justiça, por exemplo, assinalou, em julgado de 2007: "Não se descortinando elementos fácticos nítidos de onde resulte a subordinação jurídica, deverá lançar-se mão de indícios negociais, como sejam o próprio nomen conferido ao contrato...". ${ }^{130}$ Em outra ocasião, pouco tempo depois, novamente o Supremo Tribunal de Justiça invocou a "designação dada ao contrato" como indício negocial interno, a que se deve recorrer para determinar a natureza jurídica de certo vínculo jurídico. ${ }^{131} \mathrm{Na}$ mesma linha, colhe-se precedente da Corte de Cassação italiana, que retrata jurisprudência já sedimentada: "...questa Corte ha avuto già occasione di sottolineare, al fine della qualificazione del rapporto come subordinato o autonomo, il valore qualificante del momento negoziale - costitutivo e quindi dell'atteggiarsi della volontà delle parti contraenti, ove non contrastata univocamente da elementi probatori correlati alle concrete modalità di svolgimento del rapporto stesso (Cass. 4 agosto 1995 n. 8565; 17 novembre 1994 n. 9718; 2 luglio 1992 n. 8120; 10 febbraio 1992 n. 1502)". ${ }^{132}$

A qualificação contratual adquire redobrado valor, como se percebe sem grande esforço, quando se encontra envolvido na relação jurídica, como prestador de

\footnotetext{
126 GOMES, Júlio Manuel Viera. Direito do trabalho. cit., v. I, p. 139.

127 Assim, expressamente, HUMBLET, Patrick; RIGAUX, Marc. Aperçu du droit du travail belge. cit., n. 50, p. 44.

128 ICHINO, Pietro. Il contrato di lavoro. cit., p. 290.

$129 \quad$ [1980] EWCA Civ 6.

130 Processo 07S2911, Rel. Bravo Serra, decisão de 27.11.2007.

131 Processo 07S2897, Rel. Pinto Hespanhol, decisão de 13.12.2007.

132 Corte di Cassazione, decisão de 10.12.1999, processo n. 13.858.
} 
serviço, não trabalhador desprovido de informação e economicamente hipossuficiente, mas, ao contrário, pessoa de elevado nível intelectual e confortável condição econômica. As duas condições fazem com que seja mais difícil supor que a adoção do modelo contratual de prestação de serviço tenha decorrido de imposição, pelo tomador de serviço, de prática fraudulenta, apenas destinada a acobertar relação empregatícia.

É preciso ter em conta que, em se tratando de prestador de serviço de elevada condição cultural e econômica, a própria necessidade de tutela fica atenuada conquanto não deva ser posta de lado, advirta-se logo -, dado que por vezes coloca-se ele em posição de quase equilíbrio com o tomador de serviço, como bem realçado por Guilherme Machado Dray: "não deixa de ser indesmentível e irrefutável que no plano extrajurídico o progresso técnico e a exigência de trabalhadores altamente qualificados pode inverter, por vezes, a situação habitual de dependência do trabalhador em relação à entidade empregadora. A concorrência entre entidades empregadoras para a obtenção de trabalho altamente especializado poderá colocar determinado tipo de trabalhadores numa situação de real e efectiva igualdade fáctica com os seus empregadores, ou mesmo, no limite, colocá-los numa posição de supremacia na determinação das condições de trabalho". ${ }^{133}$

Ajurisprudência portuguesa, muito a propósito, enfatiza o maior valor, como indício de inexistência de subordinação trabalhista, da qualificação feita pelas partes nos contratos em que envolvido trabalhador instruído e culto. Colhe-se, sobre o tema, acórdão do Supremo Tribunal de Justiça com a seguinte ementa: "Tratando-se de contrato escrito, o nomen iuris que lhe foi dado pelas partes e o regime que nele foi consignado para regular a relação jurídica entre elas estabelecida, não sendo decisivos para a qualificação jurídica da mesma, não deixam de ser importantes para apurar a vontade real das partes, sobretudo se estas forem pessoas instruídas e cultas". ${ }^{134}$ É de referir, ainda, outro pronunciamento, mais antigo, assim sumulado: "Se é certo que o nomen juris não vincula as parte e muito menos o tribunal e que é o conteúdo real das relações contratuais, tal como se mostra assumido pelas partes que importa apurar em última análise, não é menos verdade que não se pode retirar toda a relevância à qualificação atribuída aos contratos que as partes celebram, principalmente quando os contratantes são pessoas esclarecidas..."135

133 DRAY, Guilherme Machado. O princípio da igualdade no direito do trabalho. Coimbra: Almedina, 1999. n. 241, p. 188.

134 STJ - Processo 07S2187, Rel. Sousa Peixoto, decisão de 17.10.2007.

135 STJ - Processo 01S881, Rel. Diniz Nunes, decisão de 09.01.2002. Cf., ainda, do Supremo Tribunal de Justiça de Portugal: " 1 . As actividades tradicionalmente exercidas por profissionais liberais, nomeadamente a advocacia, podem ser objecto de contrato de trabalho. 2. Quanto estejam em causa essas actividades, nem sempre é fácil determinar a natureza do contrato. 3. Para ultrapassar essa dificuldade há que recorrer aos chamados indícios da subordinação jurídica que é o elemento que verdadeiramente caracteriza o contrato de trabalho quando em confronto com o contrato de prestação de serviços. 4. A denominação dada pelas partes ao contrato é um desses indícios e terá uma relevância muito especial quando o contrato foi celebrado entre 
Ao mesmo resultado já chegaram os tribunais brasileiros. O Tribunal do Trabalho da $24^{\text {a }}$ Região, por exemplo, realçou a necessidade de distinguir, no tocante à abrangência do tratamento tutelar a conferir-se em determinada situação, o trabalhador sem recursos econômicos e desprovido de informação do prestador de serviço altamente qualificado e com amplo patrimônio. O julgado apresenta ementa com a seguinte redação: “Ônus da prova. Relação contratual entre médicos. Parceria ou vínculo de emprego. O caráter protecionista do Direito do Trabalho deve ser inversamente proporcional à capacidade intelectual, sócio-cultural e econômica do prestador de serviços, não cabendo invocá-lo quando nos dois lados da relação jurídica de direito material encontramse pessoas de intelecto privilegiado, profissionais liberais no pleno exercício daquela atividade, mesmo porque a verdadeira isonomia consiste em dar tratamento desigual aos que juridicamente se desigualam e na mesma proporção dessa desigualdade". ${ }^{136}$

Assim, se as partes mesmo adotaram livremente contrato não trabalhista de prestação de serviço, sendo o trabalhador pessoa de alta qualificação, com tirocínio empresarial e capacidade econômica significativa, a forma contratual adotada - indício a ser sempre levado em conta, juntamente com os demais, na definição judicial da verdadeira natureza da relação - torna-se de maior peso e relevo.

E o peso da forma adotada é ainda maior quando condizente com o comportamento subsequente das partes. Afinal, a conduta dos contratantes, especialmente se livre de qualquer constrangimento, é também elemento importante para a interpretação do contrato e, via de consequência, para a determinação da natureza da relação jurídica. Carlos Maximiliano observa, sob a perspectiva da hermenêutica: "a conduta posterior e concorde dos estipulantes, que tiver relação com o objeto principal, será ótimo elemento para explicar o intuito dos interessados ao celebrar o ato jurídico". ${ }^{137}$ Por isso mesmo Betti, ao repelir a ideia de que apenas a declaração, não o comportamento, adquire relevância para determinar a extensão da obrigação decorrente do negócio jurídico, enfatiza: "il comportamento ha una funzione costitutiva, non meramente probatoria, rivelativa". ${ }^{138}$ Já no campo trabalhista, pondera Camerlynck : "de même que le comportement comme employeur du bénéficiaire de la prestation fera aisément présumer l'existence d'un contrat de travail..., de manière symetrique et inverse le comportement comme professionnel indépendent de l'auter de la prestation conduira à lui refuser la qualité de salarié". ${ }^{139} \mathrm{Na}$

um Banco e um advogado com 13 anos de profissão." (STJ - Processo 04S3581, Rel. Sousa Peixoto, decisão de 03.03.2005).

136 TRT - 24 $4^{\mathrm{a}}$ Reg., Proc. n. 01249-2000-777-24-00-0, Rel. Juiz Amaury Rodrigues Pinto Júnior, RO n. 1249/2000, julg. em 26.10.2000 in DO/MS n 5397 de 01.12.2000, p. 49.

137 MAXIMILIANO, Carlos. Hermenêutica e aplicação do direito. Rio de Janeiro: Forense, 1991. n. 428, p. 350 .

138 Teoria generale del negozio giuridico, Torino, UTET, 1943, n. 11, p. 85.

139 BETTI, Traité de Droit du Travail - Contrat de Travail cit., n. 33, p. 56. 
common law, a conclusão é a mesma. A doutrina britânica registra: "the manner in wich the contract is performed is also an important guide to its contents". ${ }^{140}$

Com efeito, diante do indelével caráter contratual da relação de emprego, nunca se deve desprezar a intenção das partes e o comportamento delas na qualificação do vínculo decorrente da prestação de serviço. Se jamais pretenderam celebrar contrato de trabalho, comportando-se de modo consequente, é mais difícil, reunidos outros elementos que apontam para a inexistência da subordinação trabalhista, falar em vínculo de emprego. Por isso não deixa de ser aspecto a considerar, na determinação da natureza da relação, "whether or not the parties believe they are creating the relationship of employeremployee". ${ }^{141}$ A jurisprudência trabalhista brasileira pôde assinalar o ponto em aresto paradigmático: "Contrato de trabalho - Intenção do trabalhador. A intenção do trabalhador deve ser um dos elementos a aferir para a caracterização do contrato de trabalho. Se o trabalhador tinha a intenção de ser sócio da STFP, tanto que ajuizou ação na Justiça Comum discutindo sua condição de sócio, não se pode dizer que era empregado. O reclamante não tinha intenção de ser empregado, mas sócio, inclusive diante das atividades religiosas que desenvolvia na ré". ${ }^{142}$ A aplicação da proibição do venire contra factum proprio, decorrente do princípio da boa-fé objetiva - a despeito das inegáveis limitações que a figura ostenta ${ }^{143}$ -, ainda mais justifica a conclusão. ${ }^{144}$

140 DEAKIN, Simon; MORRIS, Gillian S. Labor Law. London: Butterworths, 2003. p. 259. De modo algo confuso, dispõe a Lei-Programa (I) belga, de 27 de dezembro de 2006: "Art. 331. Sans pouvoir contrevenir à l'ordre public, aux bonnes moeurs et aux lois impératives, les parties choisissent librement la nature de leur relation de travail, dont l'exécution effective doit être en concordance avec la nature de la relation. La priorité est à donner à la qualification qui se révèle de l'exercice effectif si celle-ci exclut la qualification juridique choisie par les parties".

141 Tieberg v. Unemployment Ins. App. Bd., 2 Cal. 3d 943.

142 TRT - 2 ${ }^{\text {a }}$ Reg., $3^{\text {a }}$ T; RO n. 02420199907502006-SP; Rel. Juiz Sérgio Pinto Martins, Ac. nº 20030464000, julg. em 26.08.03 in DJSP de 09.09.03.

143 Em termos gerais, sobre o ponto, obrigatória a citação de CORDEIRO, Antônio Menezes. Da boa fé no direito civil. Coimbra: Almedina, 2001. p. 742 e segs.

144 Para alguns exemplos de aplicação da proibição de venire contra factum proprium como fundamento para o não reconhecimento de relação de emprego, cf.: "Relação de emprego. Descaracterização. 'Venire contra factum proprium'. Prevalência da boa-fé nas relações jurídicas. A empregada que, paralelamente à relação de trabalho voluntário, aufere durante vários anos os lucros decorrentes da condição de sócia de empresa regularmente estabelecida, não logrará êxito no ajuizamento de ação pretendendo o reconhecimento de relação de emprego com percepção de parcelas contratuais e rescisórias. 'Aplicação do postulado que proíbe o comportamento contraditório - venire contra factum proprium, modalidade de abuso de direito nascida da quebra da confiança, da boa-fé nas relações jurídicas (art. 422 do Código Civil c/c art. $9^{\circ}$ da CLT)'." (TRT - $10^{\mathrm{a}}$ Reg., $1^{\mathrm{a}}$ T., RO n. 14200701910008-DF, Rel. Juiz André R. P. V. Damasceno, julg. em 22.08.2007 in DJ de 31.08.2007); "Vínculo empregatício x autônomo. Optando o trabalhador em receber percentual superior de comissões na condição de autônomo, ao invés de ter a CTPS anotada e, perdurando tal situação por mais de quatro anos, impossível o reconhecimento do liame empregatício após encerrada a relação de trabalho. Inexistência de intenção de fraudar normas trabalhistas, pois manifesta a prevalênia da vontade obreira pelo benefício do percentual comissional superior. A boa-fé na execução dos contratos é princípio geral de cunho moral que se aplica em todo complexo das relações privadas, representando respeito mútuo entre as partes no fiel cumprimento do pactuado (artigo 151 do CCB), sem contar que "O intérprete deve 
Em resumo, se a qualificação da relação jurídica feita pelas próprias partes nela envolvidas, a revelar a intenção delas, é um aspecto a ser levado em conta na definição da real natureza do liame, adquire peso ainda maior na medida em que condizente com o comportamento subsequente e quando o prestador de serviço se mostra experiente, informado e dotado de ampla capacidade econômica.

9. Exame judicial da existência ou não da subordinação própria do contrato de trabalho

Para decidir sobre a existência ou não do contrato de trabalho é necessário, como já dito, examinar o comportamento individualizado do prestador de serviço, o que implica, necessariamente, estudo casuísta da forma como se desenvolve a atividade. Daí a importância da prova testemunhal, ao lado do depoimento pessoal das partes, sempre que no processo esteja em discussão a natureza jurídica do vínculo formado entre trabalhador e prestador de serviço. É a partir da prova testemunhal e do depoimento pessoal que se pode melhor apreender a realidade fática do trabalho, nem sempre adequada e suficientemente evidenciada pela prova pré-constituída, mesmo que de caráter documental. ${ }^{145}$

Mas o valor da prova testemunhal e do depoimento pessoal depende do respeito ao princípio da imediatidade e da identidade física do juiz. Os juízes que não ouviram as testemunhas depondo, nem puderam colher o depoimento das partes, ressalta François Gorphe, em estudo dedicado exatamente à prova testemunhal, "n'ont aucun moyen d'apprécier les témoignages". ${ }^{146}$ Nas palavras de Denti, "il vero giudizio di fatto è quello che si pone in rapporto di immediatezza com l'assunzione delle prove e discende da una participazione diretta del giudice alle attività istruttorie". ${ }^{147}$

cogitar como o contrato tem sido anteriormente cumprido pelas partes, pois que são elas o melhor juízo de sua hermenêutica, devendo considerar-se que, se executou num dado sentido, é porque entenderam os contraentes que esta era a sua verdadeira intenção." (Caio Mário da Silva Pereira, citado pelo Juiz Fernando A. V. Damasceno nos autos do processo TRT - $10^{\mathrm{a}}$ RO n. 641.89, publicado no DJU de 27.02.91, p. 3143). Recurso a que se nega provimento." (TRT - $10^{\mathrm{a}} \mathrm{R}-2^{\mathrm{a}} \mathrm{T}-\mathrm{RO} \mathrm{n}^{\mathrm{o}} 5700 / 95$ - Rel. Juiz Alencar Machado DJDF 18.10.96 - pág. 18628); “Advogado. Boa-fé objetiva. Proibição do comportamento contraditório, "non venire contra factum proprium". Relação de emprego negada. Recurso improvido." (TRT - 19a Reg., RO n. 00711.2006.002.19.00-7, Rel. Juiz Nova Moreira in DJ de 11.07.2007).

145 Compreende-se, pois, considerem os tribunais haver nulidade processual, quando obstada a colheita da prova testemunhal, ainda que para confrontar a prova documental já produzida. Veja-se, a propósito, o seguinte aresto: "Sendo a primazia da realidade um dos princípios que informam o direito laboral e segundo o qual a realidade dos fatos prevalece sobre a prova documental, o encerramento da instrução processual impedindo a produção de prova testemunhal pela reclamada, caracteriza o cerceamento ao princípio do contraditório e do amplo direito de defesa”. (TRT - $2^{\mathrm{a}}$ Reg., $10^{\mathrm{a}}$ T. Ac. n. 2960215669, Rel. Juiz José R. Vinha in DJSP de 13.05.96, p. 59).

146 GORPHE, François. La critique du témoignage. Paris: Dalloz, 1927. p. 85.

147 DENTI, . Riforma o controriforma del processo civile? In: Un progetto per la giustizia. Bologna: Il Mulino, 1982. p. 288. Em termos quase idênticos, CAPPELLETTI, Mauro. Un idolo falso: el Codigo de 1942. In: Proceso, ideologías, sociedad. Buenos Aires: EJEA, 1974. p. 289. 
Assim, na avaliação da existência ou não de contrato de trabalho, a conclusão a que sobre os fatos se chega no juízo de primeiro grau, perante o qual se produziu a prova, adquire valor redobrado, sempre que respeitada a imediatidade e a identidade física. Ainda que tenha o recurso efeito devolutivo amplo, de modo a permitir, em tese, revisão tanto das conclusões sobre as questões de direito como daquelas relativas aos fatos - como ocorre com o recurso ordinário no processo do trabalho -, estas últimas merecem particular consideração pelo juízo ad quem, que as deve, em regra, prestigiar, consoante já teve oportunidade de enunciar a jurisprudência. ${ }^{148}$

10. Subordinação: questão de fato ou questão de direito?

Sem embargo do assinalado anteriormente, não se deve imaginar que toda a discussão sobre a existência ou não de contrato de trabalho, inclusive pela avaliação do caráter subordinado ou não do trabalho, fique limitada, sempre e necessariamente, ao exame de fatos e provas. É verdade que não poucas vezes se afirma ser assim, especialmente me jurisprudência. É paradigmático de tal entendimento o seguinte precedente: "Relação de emprego é matéria que tem delineamento fático probatório que não comporta revisão no recurso de revista, ante o que dispõe o Enunciado da Súmula de jurisprudência do TST de n. 126". ${ }^{149}$ Conferir excessiva abrangência à proposição de que a decisão sobre a

148 De acordo com o assinalado, em jurisprudência: "Prova. Convicção do juiz. Ninguém é mais apto para estabelecer com quem está a verdade do que o próprio juiz que tomou os depoimentos das testemunhas. Somente ele manteve o contato direto com a prova, medindo-lhe a postura e as reações, diante das perguntas. Neste caso, o mesmo juiz instruiu e julgou o processo. E, sendo assim, apenas em situações em que fique comprovadamente demonstrado que a testemunha faltou com a verdade é que se pode reformar a sentença..." (TRT - 2a Reg., 12 ${ }^{\mathrm{a}}$ T., RO n. 02230200700502009 , Rel. Juiz Delvio Buffulin, Ac. n. 20100052643 in DOE de 26.02.2010); "Prova testemunhal. Valoração. Prevalência, como regra, do convencimento do Juiz que colheu a prova. Deve ser prestigiado, como regra, o convencimento do juiz que colheu a prova Ele, afinal, é que manteve o contato vivo, direto e pessoal com as partes e testemunhas, mediu-lhes as reações, a segurança, a sinceridade, a postura. Aspectos, aliás, que nem sempre se exprimem, que a comunicação escrita, dados os seus acanhados limites, não permite traduzir. O juízo que colhe o depoimento "sente" a testemunha. É por assim dizer um testemunho do depoimento. Convencimento, portanto, melhor aparelhado e que, por isso, deve ser preservado, salvo se houver elementos claros e contundentes em contrário. Recurso da autora a que se nega provimento." (TRT - $2^{\mathrm{a}}$ Reg., $11^{\mathrm{a}}$ T., Ro n. 00112006920105020261 (00112201026102006), Rel. Juiz Eduardo de Azevedo Silva, Ac. n. 20101279889 in DOE de 18.01.2011) e "Horas extras. Ao contrário de outras áreas do Direito, no Direito do Trabalho, a luz do princípio da primazia da realidade, a prova oral tem espaço privilegiado. Neste tipo de prova, a linguagem verbal não é a única comunicação, ela também é formada por gestos, fisionomia, tom de voz, postura etc. É o que se chama de linguagem do corpo, bem mais espontânea e de difícil dissimulação. Referida metaliguagem é do alcance exclusivo do Juiz de origem, o qual presenciou a audiência. Portanto, sua valoração da prova oral deve ser vista com bons olhos, devendo ser rechaçada apenas nos casos de notória contrariedade das provas..." (TRT $-2^{\mathrm{a}} \mathrm{Reg} ., 10^{\mathrm{a}} \mathrm{T}$., RO n. 01483002320105020049, Rel. Juíza Marta Casadei Momezzo, Ac. n. 20110227675 in DOE de 03.03.2011).

149 TST $-3^{\mathrm{a}}$ T., RR n. 5.785/86, Rel. Min. Orlando Teixeira da Costa, Ac. n. 1.260, julg. em 12.05.87 in DJU de 12.06.87, p. 11.959. Sempre na mesma linha: "Agravo de instrumento. Recurso de revista - Do vínculo empregatício com advogado. $\mathrm{O}$ fato de o Reclamante ser advogado militante não impede o reconhecimento do vínculo empregatício. A conclusão do Tribunal Regional no sentido de reconhecer a existência de relação 
existência ou não de contrato de trabalho supõe exame de fatos e provas leva a resultado distorcido e equivocado.

A avaliação da forma concreta como se dá a prestação de serviço certamente implica julgamento sobre fatos e provas. Nas palavras de jurisprudência norte-americana, "the determination of employee or independent-contractor status is one of fact if dependent upon the resolution of disputed evidence or inferences". ${ }^{150}$ Afinal, questão de fato é, no fundo, questão relativa ao que se passou, ao que aconteceu. ${ }^{151}$ Fatos são acontecimentos. ${ }^{152}$ Dizer, por exemplo, se o trabalhador estava sujeito a horário controlado ou não, se era obrigado a prestar contas de suas atividades ou não, se trabalhava em casa ou no estabelecimento da empresa, se deveria comparecer diariamente à empresa ou não, etc., supõe apreciar fatos. Há que sopesar os depoimentos prestados, considerar os documentos juntados aos autos, apreciar, enfim, a prova produzida.

Já a qualificação jurídica dos fatos apurados - quer dizer, a consequência jurídica dos fatos estabelecidos - é, como regra geral, atividade diversa. Nas palavras de Chiovenda, "não constitui questão de fato ou juízo de fato, mas de direito, a concernente à natureza jurídica de um fato, a saber, se um fato considerado como verdadeiro é ou não regulado por determinada norma". ${ }^{153}$ Pontes de Miranda, a seu turno, é categórico ao

de emprego, nos termos do art. $3^{\circ}$ da CLT, com base na análise dos elementos fático-probatórios presentes nos autos, é insuscetível de revisão, pois, para se chegar a entendimento contrário, seria necessário o reexame dessas provas, o que é vedado nesta fase recursal, nos termos do Enunciado n. 126 do TST. Agravo a que se nega provimento." (TST - 5 T., AIRR n. 1205-1999-003-19-40, Rel. Min. Rider Nogueira de Brito, julg. em 29.10.03 in DJU de 28.11.03); "Vínculo de emprego. Matéria fática. A pretensão da parte em obter a reforma do acórdão recorrido, mediante o qual se deferiu o pleito de reconhecimento de relação de emprego com supedâneo nos elementos de prova, demanda o revolvimento do conjunto probatório, o que é vedado nesta esfera extraordinária, a teor da Súmula n. 126 do Tribunal Superior do Trabalho. Agravo de instrumento a que se nega provimento." (TST - $5^{\mathrm{a}}$ T., AIRR - 581/2005-070-01-40, Rel. Min. Emmanoel Pereira, in DEJT - 11.09.2009). Na jurisprudência comparada, encontra-se pronunciamento do mesmo teor, em julgado da Corte de Cassação italiana, verbis: “...l'apprezzamento, in concreto, circa la riconducibilità di determinate prestazioni ad un rapporto di lavoro subordinato o autonomo si risolve in un accertamento di fatto che, ove adeguatamente e correttamente motivato, in rapporto ad un esatto parametro normativo, è incensurabile in Cassazione." (Cassazione, Sez. Lavoro, sentença de 20.06.2003, n. 9.900).

150 S. G. Borello \& Sons, Inc. v. Department of Industrial Relations (1989) 48 Cal.3d 341, 256 Cal. Rptr. 543; 769 P.2d 399.

151 Sobre a distinção entre questão de fato e questão de direito, com considerações das dificuldades teórica de estabelecê-la, mais amplamente, com várias indicações bibliográficas, cf. MALLET, Estêvão. Do recurso de revista no processo do trabalho. São Paulo: LTr, 1995. n. 11, p. 101 e ss. Acrescentem-se as observações de François Rigaux em A lei dos juizes. Lisboa: Instituto Piaget, s. d. p., p. 51 e ss., e o comentário de Proto Pisani, para quem "la distinzione tra norma, diritto concreto e fato, se è relativamente semplice in astratto, puo divenire estremamente problematica in concreto o quanto meno dare luogo a problemi di grossa delicatezza" (PISANI, Proto. La tutela di mero accertamento. In: Appunti sulla giustizia civile. Bari: Cacucci, 1982. p. 94).

152 Francisco Cavalcanti Pontes Miranda de define fato como o que "ocorreu, ou ocorre, ou vai ocorrer" (MIRANDA, Francisco Cavalcanti Pontes. Tratado de direito privado. cit., tomo I, $\S 1^{\circ}$, n. 2, p. 3). O que ocorre certamente é fato. O que vai ocorrer é, antes de que tenha ocorrido, mera hipótese, não fato.

153 Instituições de direito processual civil. São Paulo: Saraiva, 1945. v. III, n. 414, p. 415. 
escrever: "as questões de classificação e de qualificação são questões de direito, e não de fato". 154

Assim, a partir de certos fatos - a existência de controle de horário, a sujeição a ordens e a obrigação de comparecimento diário ao local de trabalho, por exemplo -, decidir se o trabalho se desenvolvia de forma subordinada ou autônoma é, na verdade, juízo de direito. Como assinalou o Supremo Tribunal de Justiça de Portugal, “a qualificação de um contrato...é matéria de direito". ${ }^{155}$ Analogamente, decidiu a Corte de Cassação francesa que "s'il appartient aux juges $d u$ fond de constater souverainement les faits d'ou ils deduisent l'existence ou l'absence d'une faute delictuelle ou quasi delictuelle, la qualification legale de ces faits releve du controle de la cour de cassation". ${ }^{156}$ Determinase, a partir dos fatos considerados provados, a norma jurídica incidente, o art. 442, caput, da CLT, o art. 593, do Código Civil, ou outra. Atividade eminentemente jurídica, portanto.

Por conseguinte, a controvérsia sobre a natureza subordinada do trabalho e, via de consequência, sobre o caráter trabalhista ou não do vínculo pode, a depender da forma como se coloca, dar margem a reexame em recurso de natureza extraordinária, especialmente em recurso de revista, sem contraste com o teor da Súmula 126, do Tribunal Superior do Trabalho. ${ }^{157}$ Não há como questionar a conclusão, formulada quando do julgamento do recurso ordinário, sobre os fatos apurados. Não se pode entender que não havia controle de horário ou que não havia obrigação de comparecimento diário à empresa. Nada obsta, todavia, chegue-se, em julgamento de recurso de revista ou de embargos, a resultado diverso do pronunciado no Tribunal Regional do Trabalho, em torno da natureza jurídica da relação, a partir de enquadramento jurídico diverso dos mesmos fatos afirmados na decisão recorrida. Bem a propósito, decidiu o Supremo Tribunal Federal:

154 Comentários ao Código de Processo Civil. Rio de Janeiro: Forense, 1949. v. V, p. 304. No mesmo sentido, entre tantos autores, MATTIROLO, Trattado di diritto giudiziario civile italiano. Torino: Fratelli Bocca, 1896. n. 910, p. 1024; ZANZUCCHI, Il nuovo diritto processuale civile. Milano: Giuffrè, 1942. v. I, p. $243-$ 244; CARNELUTTI, Francesco. Instituciones del proceso civil. Buenos Aires: EJEA, 1973. v. II, n. 577, p. 260. Mencione-se, ainda, o clássico estudo de MARTY, La disctinction du fait et du droit. Paris: Sirey, 1929. n. 115 e ss., p. 204 e ss. Para arrematar, vale reproduzir a advertência de Inocêncio Galvão Telles para quem "a qualificação jurídica de certa convenção é uma questão de direito e não uma simples questão de fato." (Manual dos contratos em geral. cit., n. 131, p. 254-255).

155 Acórdão de 01.06.1973 apud Abílio Neto, Código de Processo Civil anotado, Lisboa, Ediforum, 1997, ementa n. 36, p. 826. O Supremo Tribunal Federal brasileiro considerou, acertadamente, ser de direito a questão de saber se determinado ajuste negocial constitui simples contrato preliminar ou verdadeira locação (STF - 2 a T., Proc. RE n. 69.648-MG, Rel. Min. Adalício Nogueira in Revista Trimestral de Jurisprudência, v. 66, p. 108-109) e se determinada situação de fato tipifica fideicomisso ou usufruto (STF - $1^{\text {a }}$ T., Proc. RE n. 73.212-GB, Rel. Min. Djaci Falcão in Revista Trimestral de Jurisprudência, v. 70, p. 394).

156 Chambre civile 2, decisão de 22.02.1967. Nos tribunais norte-americanos aduz-se que, definidas as respostas sobre a forma como se dá a prestação de serviço, a determinação da natureza empregatícia ou não da relação jurídica "becomes one of law" (S. G. Borello \& Sons, Inc. v. Department of Industrial Relations (1989) 48 Cal. 3d 341, 256 Cal. Rptr. 543; 769 P.2d 399).

157 "Incabível o recurso de revista ou de embargos (arts. 896 e 894, "b", da CLT) para reexame de fatos e provas". 
"Não se deve confundir o reexame dos elementos probatórios contidos no processo com o enquadramento jurídico dos fatos constantes do acórdão proferido e impugnado mediante recurso de natureza extraordinária. É vedada a primeira prática, mostrando-se a segunda indispensável a que se conclua pela adequação, ou não, do recurso". ${ }^{158}$

\section{Conclusão}

A subordinação, elemento essencial para a caracterização do contrato como sendo de trabalho, supõe mais do que a mera sujeição a certas obrigações, o que se encontra em qualquer relação contratual, inclusive em contratos civis de prestação de serviço. Supõe a prerrogativa, conferida ao tomador de serviço, de, durante o exercício do trabalho, estabelecer concretamente as diretrizes a serem observadas pelo trabalhador. Varia, porém, sua intensidade, conforme a natureza da atividade, a função do empregado, etc. Sua identificação - por meio de operação que envolve qualificação jurídica dos fatos, suscetível de revisão em recurso de natureza extraordinária, portanto - reclama exame da forma como se desenvolve a atividade e pode ser feita também a partir de indícios, entre os quais não deixam de ter peso, conquanto não sejam decisivos, como nenhum outro indício é, a qualificação da relação jurídica feita pelas próprias partes nela envolvidas e o comportamento por elas adotado.

São Paulo, dezembro de 2012.

158 STF $-1^{\text {a }}$ T., HC n. 89.493/SP, Rel. Min. Marco Aurélio, julg. em 28.11.2006 in DJU de 09.02.2007, p. 30. Sempre na mesma linha, em matéria processual penal, para delimitar a abrangência da excludente de cabimento do habeas corpus relacionada com o reexame de fatos e provas, registrou o Supremo Tribunal Federal: "Habeas corpus. Qualificação de fato incontroverso. Crime culposo. Nexo causal. Justa causa. 1. Não se trata de reexame de prova, quando incontroverso o fato se afere o seu correto enquadramento legal." (STF $-1^{\text {a }}$ T., HC n. 61.826/SP, Rel. Min. Rafael Mayer, julg. em 22.06.1984 in DJU de 05.10.1984, p. 16.449) e "Não constitui reexame de matéria fático-probatória a análise, em cada caso concreto, da força probante dos elementos de prova relativos a fatos incontroversos." (STF - 1 ${ }^{\mathrm{a}}$ T., RHC n. 91.691/SP, Rel. Min. Menezes Direito, julg. em 19.02.2008 in DJe n. 74, divulg. em 24.04.2008, public. em 25.04.2008). Sem razão, portanto, Pontes de Miranda quando afirma, de maneira genérica e em contradição com sua proposição citada anteriormente no corpo do texto, em torno da atividade de qualificação jurídica dos fatos, que saber "se o vendedor, o agente ou o representa comercial é empregado, no sentido da legislação do trabalho... é questão de fato." (MIRANDA, Francisco Cavalcanti Pontes de. Tratado de direito privado. cit., tomo XLVII, § 5.097, p. 99). 